\title{
Beyond Eusebius: Prefatory Images and the Early Book
}

\begin{abstract}
This paper explores the genesis and functions of visually-conceived prefatory matter in the creation of the book in late antiquity. Beyond pragmatic use of prefaces to help guide readers through the new structure of the composite or collected set of texts, which is what a codex constitutes, the chapter examines the multiple interpretive impacts of various kinds of prefatory images as they resonate in the structure and reception of the early book. From the start, prefatory structures for the written codex included visual ornamentation: the kinds of framing needed to help readers find their way through this new kind of artefact intrinsically sought pictorial as well as textual cues.
\end{abstract}

When you open the book you are reading now, almost unnoticed as you move beyond the tabulated contents to the pages you are interested in, is a whole apparatus. There is, at the opening, the title, the series in which the books sits (if it has one), the author or editors and a range of paraphernalia that includes publisher, place of publication, year of publication (and perhaps years of earlier editions), printer and year of printing, claims of copyright and a series of cataloguing data from Library of Congress control numbers (for books published to be circulated in North America) to ISBN numbers. All this is almost unnoticeable even before the inception of the book itself-blurb, endorsements, contents pages, prefaces, acknowledgements, foreword, introduction. Through the text, in addition to page numbers, there may be running heads and author names for articles in a collection, and at the end of the main matter a series of indices and bibliographies. What I am describing-and of course there are multiple variations and no standard form across all the

This article is dedicated to the memory of Judith McKenzie, who urged me to work on canon tables and inspired me with her new material as well as her reflections on the Garima Gospels (even though she and I did not always agree). She died tragically and much too early in May 2019. I want to record my thanks also to the Centre for the Study of Manuscript Cultures at Hamburg, for organizing the landmark conference on canon tables out of which this book has emerged, to all the participants for their excellent papers and discussion, and above all to the wonderful trio of Hanna Wimmer, Bruno Reudenbach and Alessandro Bausi (in reverse alphabetical order) for their organization, engagement and making it all possible. languages and book cultures of the contemporary worldis the paraphernalia of the book, that which bestows conviction in its readers that it is a trustworthy product, well edited, externally reviewed, responsibly published, ready and able to be handed out to the young, the impressionable, those keen to learn. For centuries these things have been part of the material rhetoric of the book, its claims to validity and its appeal to the confidence of its readers. This apparatus, which is currently still in place even if you read the book online-is both a kind of comfort and a form of authorisation. We take it so much for granted, that we hardly notice it.

In exploring the Eusebian apparatus, created in the early fourth century for the Christian codex, we are doing nothing less than examining the genesis of this paraphernalia for the whole history of the book. ${ }^{1}$ Perhaps only at the moment-maybe just the beginning of a processwhen we can imagine the death of the book through its transformation into whatever the digital world will create beyond our current experiments with e-books and tablets and online reading, are we at last placed to look at the work of Eusebius, beyond simply taking for granted his extraordinary achievement in creating his apparatus for the manipulation and use of the Gospels. For, despite centuries of ignoring the colossal achievement of what was effectively the invention of the technology for navigating the codex, and worse of despising this achievement on the part of those for whom use of the Eusebian invention is second nature (with the characteristic self-hatred that scholars reserve for earlier versions of themselves!), we have to acknowledge the absolutely monumental contribution that he made-quite beyond the Christian codex per se-to the entirety of book culture and hence academic study in the history of intellectual life that followed him. My claim may seem over the top, but I believe it simply to be no more than the truth.

As others will argue in much greater depth in this volume, Eusebius' achievement in respect of his Canons, was the creation of a threefold model for the textual

1 For the revolution from roll to codex, see Roberts/Skeat 1983; Blanck 1992, 75-101; Cavallo 1997, 85-114; Mazal 1999, 125-151; Cavallo 2010, 9-19; Schipke 2013, 143-152. For the Christian book, see e.g. Halbertal 1997; Gamble 2000; Stanton 2004, 40-49; Grafton/Willams 2006; Klingshirn/Safran 2007; Wallraff 2013a; Stroumsa 2014. 
imbrication of the four gospels into a single unit. ${ }^{2}$ It consisted of 1) the prefatory Letter to Carpianus, which was an explanation of what he had done and also a series of instructions to the reader about how to use the model, 2) the series of tables themselves showing the parallels where two or more gospels described the same event or an event without parallels unique to a single gospel, typically placed within arcaded arches and numbered according to 3) the marginal annotations by verse and table throughout the text of the four gospels, which enabled the comparisons to be made and the tabular parallels to be checked. ${ }^{3}$ Effectively, he had provided not only a model of running reference and indexing which remains in force today (much more precise than pagination), but he had also supplied a paratextual and commentarial explanation (actually couched in a brief, simple and helpful form) for how to make best use of what his scholarship had supplied. ${ }^{4}$ Narrowly, within Christian studies, we may see this as a brilliant technical and scholarly solution to using the gospels, which ideologically affirmed their unity and implicitly contested other models of claiming that unity (such as Tatian's Syriac Diatessaron, which put the four together into one but failed to preserve their independence or integrity). ${ }^{5}$ But more broadly, we may understand the Eusebian apparatus as a proposition for how to structure and use the codex as such, created in the early fourth century at the inception of the most far-reaching transformation of book production before the invention of printing. That proposition, perhaps because Eusebius had the backing of the emperor, perhaps because his technology of reference and comparison was indeed so brilliant a tool, won out across the history of the medieval book as the overweening model for the paratextual manipulation of texts and for their scholarly usage. Indeed, since the printed book effectively preserved the model of the codex in almost every respect except that it could be mass produced on cheap paper instead of expensive parchment, Eusebius represents the most thoughtful intervention in the use of the book as a technology and a gadget, ${ }^{6}$ before

2 Beyond the discussions in this book, key contributions are Grafton/ Williams 2006, 194-200; Wallraff 2013a, 25-37; Crawford 2019, (and I am hugely grateful to the author for letting me see this in advance of publication).

3 The classic discussion-dated, perhaps, but fundamental-remains Nordenfalk 1938. See also Wessel 1976-1977; Nordenfalk 1982; Nordenfalk 1984; Sevrugian 2004; Crawford 2019, 96-122.

4 On paratexts, see Genette 1997 with e.g. Jansen 2014 and Crawford 2019, chapter 1, 21-54.

5 On the Diatessaron traditions, see Schmid 2013; Crawford 2015. 6 It is significant that Eusebius extended the technology by creating the radical transformations we face today in the rise of digital media, which will surely culminate in the eclipse of the book in the face of internet models of digital textuality.

That is, Eusebius's model for prefatory materials as a form of index coupled with referential numbering through the text, represents the pattern which the entire history of the codex-book has adopted down to the present daywith numerous adaptations, to be sure. We need to look well beyond Christianity to see Eusebius's interventions not only as contributions to how one might think about Christian texts but much more broadly as paradigms of practical and organisational aids for the kinds of collected volumes that integrated works which once occupied many rolls of papyrus. Thus the question of the unity of the gospels is not only a significant theological one, but a very practical and material one: for the first time, in the vellum codex (whose cost but also longevity was in an entirely different category from the papyrus roll), it was possible to collect the four gospels in one volume (rather than several rolls), indeed to collect the entire Bible, including the Old Testament. That possibility for producing a collected edition of an entire work, such as, the 12 books of the Aeneid, the 24 books of the Iliad, or the entire published corpus of an author, such as the Eclogues, Georgics and Aeneid of Vergil or the six surviving plays of Terence, was open to the entirety of surviving Classical literature as well as to the Christian Scriptures. It was this possibility for complete editions and its rich exploitation in late Antiquity (despite the fact that hardly any examples of original codices are extant)-as well as the persistent copying of manuscripts throughout the Middle Ages in the Christian parts of western Asia and North Africa, in Byzantium and in the West, not to speak of the remarkable culture of translation and copying into the many languages and worlds of the Christian and later Islamic Eastthat enabled a canon, in the sense that we understand the writings of Antiquity, to be created and preserved. ${ }^{7}$

Key to the Eusebian apparatus is the need for extensive front matter, both the Letter to Carpianus (explaining how to use the new format) and the tabulated arcades, which were swiftly susceptible to fine decorative illumination. This is more than a form of prefacing-it is a model of framing the whole codex as artefact (textual and pictorial) in which introductory paratexts (such as the letter

a second set of tables for the Psalms, a crucial text for the performance of liturgy, apparently also set into arcades, capable of ornamentation: See Wallraff 2013b.

7 For a useful account of canons and canon-formation, see Gorak 2013, 9-44 for the early history in the Greek tradition. 
to Carpianus, or that of Jerome to Pope Damasus for his translation of the Bible, or-at the same time but not in the tradition of the Christian book-Ausonius' letter to Paulus which prefaces his Cento Nuptialis) ${ }^{8}$ plays an increasing role. ${ }^{9}$ This interest in framing the artefact extends to the single page and the double page spread, especially in illuminated manuscripts. The Eusebian paratext that frames the gospel pages themselves is a relatively restrained numbering, but the tradition of placing scholia (often written in minuscule against the majuscule of the main text) in relation to a poem or an image on the same page or facing page is rampant by the Carolingian period, and may well emulate models from the earliest fourth century codices. One might cite ninth century codices of the poems of both Optatian Porphyry and Aratus. ${ }^{10}$

In other words, other precious and rare evidence of front matter from the late antique codex must be marshalled to play alongside the Eusebian material in an exploration of how the early codex came into being as an artefactual apparatus, a material product for the transmission of knowledge and education to its readers. Notably the book-technology of numerical tabulation arranged in columns and arcades (not however prefatory) was already available in ancient astronomy, both rolls and early codices. ${ }^{11}$ Beyond the pragmatics of the use of prefaces to help guide readers through the new structure of the composite or collected set of texts, which is what a codex constitutes, I will in this paper speculate about the multiple interpre-

8 See Green 1991, 132-134 and Prieto Domínguez 2010, 201-210. For discussion of Ausonius' letter, see e.g. Polara 1990, 247-251, Pollmann 2004, 80-83; McGill 2005, 1-30; Hinds 2014, 188-190; Pelltari 2014, 70-71 and 104-107.

9 For prefaces and prefatory paratexts in late Antiquity, see esp. Pelltari 2014, 45-72; Harrison 2017. For a range of reflections on ancient framing see Platt/Squire 2017.

10 For Optatian e.g.: Codex Palatinus Latinus 1713 (ninth Century), Vatican: http://digi.ub.uni-heidelberg.de/diglit/bav_pal_lat_1713/000 (last accessed 13/04/2020). Note that here the scholia (in minuscule) sometimes even takes on the figural forms of the (majuscule) poems it discusses and also partakes of the different colours of the ink used for the main poems. For Aratus, e.g.: Harley MS 647 (ninth century), British Library: http://www.bl.uk/catalogues/illuminatedmanuscripts/ILLU MIN.ASP?Size=mid\&IllID=15407 (last accessed 13/04/2020). Note that here the various commentarial texts are incorporated within the illustrations as well as outside them.

11 For papyrus tables, see e.g. Jones 1999a, 113-171, 231-245 and Jones 1999b, 299-340. Interestingly Ptolemy's (second century CE) 'Handy Tables' (computed for the longitude of Alexandria, from the death of Alexander) survive now only in the fourth century CE version of Theon of Alexandria: See Pedersen 2011, 397-400. For Ptolemy's tables, see e.g. Roby 2017, 534-541; Crawford 2019, 43-53 and the great ninth century Vatican Ptolemy, probably a copy of a late antique codex (Vat. Gr. 1291, https://digi.vatlib.it/view/MSS_Vat.gr.1291) (last accessed 13/04/2020). tive impacts of various kinds of prefatory images as they resonate in the structure and reception of the early book. It matters here, and is intrinsically interesting beyond my own disciplinary preoccupations as an art historian, that from the start prefatory structures for the written codex included visual ornamentation. ${ }^{12}$ The kinds of framing needed to help readers find their way through this new kind of artefact intrinsically sought pictorial as well as textual cues. In fact, when we think of the Codex as artefact, we need to think synaesthetically: in addition to the textures of parchment and binding, made to be touched and turned, and to the smells of glue and leather, changing as a book ages, as well as to the visuals (writing, yes, but also pictures and other forms of ornament) we need to add the demand to read aloud-central of course to the book as a performative technology of liturgy. ${ }^{13}$

From the visual point of view, writing itself is as potentially decorative and ornamental as art. In the visual articulation of the earliest codices of the fourth century, much experimentation is clearly to be expected, as a new kind of artefact was created, and traditional models of reading and learning adapted to it. In the ninth century Carolingian version-perhaps a direct copy-possibly of a fourth century codex of the poems of Constantine's Praefectus Urbi in 329 and 333, Optatian Porphyry, ${ }^{14}$ there is a fascinating use of fine letter forms executed in multicoloured inks to render Optatian's remarkable picture poems, according to a series of models-initial lines or the first letters of each line in a different colour (effectively variations of a rubric form, such as Eusebius proposed for his numerical apparatus), alternate lines in different colours, internal verses in rubric and with frames (sometimes with added floral decoration). ${ }^{15}$ But

12 Good survey discussions of the beginnings of biblical illumination (itself only a subset of the larger issue of the illustration of the codex) include Grabar 1968, 87-94; Kozodoy 1971; Lowden 1999; Kessler 2008. A collection of many of the prime images with some discussion is Sörries 1993.

13 The wildest convergence of columnar architecture, tabulation and liturgy that I have come across, and one that gives pause for thought about ways that tabulation and arcading in the book came to be deeply and subconsciously impressed on the culture of Christian liturgy, is the evidence of tables of liturgical sequences inscribed onto the columns of the Parthenon in Athens during its long life as a church. See Alexopoulos 2015, 164-174.

14 For the argument that Optatian produced 'not an unfolding scroll [...] but [...] a bound codex', see Squire 2017a, 71. On Optatian Porphyry, see Polara 1971; Squire/Wienand 2017; Squire/Whitton 2017; Squire 2017b.

15 The principal early manuscripts are: Codex Bernensis 212 (ninth century), Burgerbibliothek Bern; Codex Berolinensis Phillippicus 1815 (eighth-ninth century), Staatsbibliothek Berlin; Codex Eporediensis LXX (ninth century), Biblioteca Capitolare, Ivrea, Turin; Codex Palatinus 
most spectacularly, the late antique codex appears to have harnessed the power of lavish decorative ornamentation as well as pictorial imagery to its prefatory schematics. Frontispieces include architectural vignettes and arcades or arches with titles or with the Eusebian canons, author portraits encapsulating the character of the book's voice (much as the author photograph is still frequently used) and narrative images which are not illustrations of a prior text (by contrast with pictures that run alongside the narrative within a given book) so much as prefatory encapsulations of the totality of a poem or book through the pars pro toto model of the abbreviated narrative or thematic summary. These very different artistic strategies have different effects and emphases in how a book is to be received by its reader, and experimentation in this genre is a striking (and highly under-examined) aspect of the creativity of the deluxe codex in its early phase. Such issues would themselves attract ecphrasis and verbal exegesis in the later tradition, notably in the seventh century poem on the canon tables by the Irish monk Ailerán, ${ }^{16}$ and two Armenian ecphrases one attributed to Step'anos Siwnec'i (eighth century) ${ }^{17}$ and the other by Nersēs Šnorhali (twelfth century) which discusses the 'flowery sculptures of multicoloured hue' and the many birds that appear in the normative visual elaboration of the Eusebian tables. ${ }^{18}$ This move to exegesis of the tables is itself evidence of how the apparatus of Scriptural canonisation would come to be itself perceived as canonical in due course. And the canonicity of the codex is enshrined in monumental art as early as the fifth century where not only do Christ and the saints carry books in so many representations, but the codex comes to be enthroned in its own right as an object of visual veneration. ${ }^{19}$

Latinus 1713 (ninth century), Vatican City: http://digi.ub.uni-heidel berg.de/diglit/bav_pal_lat_1713/000 (last accessed 13/04/2020); Codex Parisinus 2421 (ninth century), Bibliothèque nationale de France, Paris; Codex Vaticanus Reginensis 733 (tenth century), Vatican City; DCL B.iv.9 (tenth century), Durham Cathedral, Durham. Michael Squire tells me there are more.

16 See Netzer 1994, 205-206, with further discussion at 61; MacLean 2003. On the Irish exegetic tradition more broadly, see esp. Mullins 2014.

17 Translated by James Russell in Mathews/Sanjian 1991, 206-207. 18 Translated by James Russell in Mathews/Sanjian 1991, 207-211, with Crawford 2019, 248-284 and the discussion of Varduhi Kyureghyan in this volume.

19 For instance the four codices placed on altars between chairs with jewelled crowns within curved architectural exedrae in the outer circle of the dome of the Orthodox baptistery at Ravenna, see Deichmann 1974, 42; or the case with four codices of the Evangelists in the south lunette of the Mausoleum of Galla Placidia, with Deichmann 1974, 77-8.

\section{Pictorial openings in the ancient book}

I want here, in the spirit of a volume dedicated to the impact of the Eusebian canons, to comment on what might be called prefatory architecture-which is a bigger topic than has been allowed in the literature and one that we find in the West as well as in the East, and also in the early Islamic book. If we take the early Biblical codices, then beyond their commitment to Eusebius' canon tables articulated as architecture (often of spectacularly ornamental kinds), they look to a strong late antique tradition that emphasised the architectural pictorial frontispiece. This tradition-alongside author portraits and painted narrative summaries at book openings-probably goes back, before the surviving manuscripts we possess and before the Eusebian Canons, to the roll and to ancient book production. ${ }^{20}$ In particular, a frequent way of opening a number of Greco-Roman literary genres in prose-the ancient novel, declamations and some popular philosophical texts-was to present a described picture as the prefatory vignette before the main text. Classic examples include the ecphrastic paintings that open the Greek romances Daphnis and Chloe by Longus and the adventures of Leucippe and Clitophon by Achilles Tatius, ${ }^{21}$ as well as a number of prefaces (or prolaliae) by Lucian, notably his Zeuxis, Herodotus and Heracles. ${ }^{22}$ But there is also a significant tradition of described prefatory architecture-for instance, Lucian's de domo and his Hippias or the Bath, ${ }^{23}$ but also elements of the Tabula or Pinax ascribed to someone called Cebes (esp. Pinax 1). ${ }^{24}$

The ecphrases of pictures are effectively narrative summaries or entrés into the main text by means of a descriptive paratext-and as such they anticipate the kinds of pictorial summaries we find at the opening of books in a series of late antique or early medieval manuscripts. One might cite, for abbreviated narrative cycles in

20 For traditions of portraits combined with tituli or captions transmitted in rolls, associated especially with Varro, see Pliny the Elder, Natural History 35.11 with Small 2003, 131-134 or Wallace-Hadrill 2008, 231-237. For some aspects of Varro's reception in late Antiquity (but eschewing any discussion of portraits painted in books), see Vessey 2014.

21 On the novels, see e.g. Kestner 1973-1974; Bartsch 1989, 109-143; and Morales 2004.

22 On Lucian's ecphrases, see e.g. Maffei 1994 and Dubel/Pigeaud 2014. For some discussion: Borg 2004, and Möllendorf 2004.

23 See esp. Thomas 2007, 221-235. On de domo: Goldhill 2001, 160167; Newby 2002; Goeken 2009. On Hippias: Cannatà Fera 1998.

24 On Cebes, see now Squire/Grethlein 2014, with earlier bibliography. 
pictorial form, the prefatory panel of six pictures framed in red before the third Georgic in the Vatican Vergil (fol. 1r), ${ }^{25}$ or the Passion cycle in the St Augustine Gospels which is part of the prefatory matter to Luke (fol. 125r, Fig. 1$).{ }^{26}$ For single summary images, there are the pictorial idylls that preface the first, third, fifth and seventh Eclogues (fols 1r, 6r, 11r and 16v, see Fig. 2) and the wonderful double page spread at the start of the third Georgic (fols $44 \mathrm{v}$ and 45r) in the Roman Vergil $;{ }^{27}$ the fine miniatures at the heads of some books, such as Exodus, Numbers, Job and Proverbs, within the sixth or seventh century Syriac Bible in Paris (Syr. 341, see Fig. 3); ${ }^{28}$ the full page miniatures of Biblical events that constitute part of the prefatory matter of the sixth century Rabbula Gospels (fols 13a, 13b, 14a and 14b), ${ }^{29}$ and the tenth century Etchmiadzin Gospels (fols 228 and 229), ${ }^{30}$ but may be earlier and have been bound in at a later time; ${ }^{31}$ let alone the Old and New Testament vignettes that appear as marginal images in the canon tables of Rabbula Gospels (fols 3b-12a), or the New Tes-

25 Biblioteca Apostolica Vaticana (hereafter BAV), MS Vat. lat. 3225, fol. 1r: see https://digi.vatlib.it/view/MSS_Vat.lat.3225 (last accessed 13/04/2020) and Wright 1993, 7-9. This is now poorly preserved. For a range of fine seventeenth century copies including several purchased for the dal Pozzo paper museum, see Claridge/Herklotz 2012, 335-351. 26 Cambridge, Corpus Christi College, Parker Library, MS 286, fol. 125r: see https://parker.stanford.edu/parker/catalog/mk707wk3350 (last accessed 13/04/2020) and Wormald 1954, 2-5 (for arrangements of prefatory matter) and 11-16 (for the rectangular miniature).

27 BAV, MS Vat. lat. 3867, fols 3v, 9r, 14v; Wright 2001 and https:// digi.vatlib.it/view/MSS_Vat.lat.3867 (last accessed 13/04/2020).

28 Paris, BnF, MS syr. 341, fols 8r, 25r, 46r and 118r. See Leroy 1964, with discussion of MS syr. 341 at 209-219 and esp. Sörries 1991, 22-26 (Exodus), 27-28 (Numbers), 29-31 (Job), 33-36 (Proverbs) and Sörries 1993, 90-91, plates 47-48.

29 Florence, Biblioteca Medicea Laurenziana, Plut. 1.56. Cecchelli, Furlani, and Salmi, 1959; Leroy 1964, 139-197; Bernabò 2008c; http://teca.bmlonline.it/ImageViewer/servlet/ImageViewer?idr=TECA0000025956\&keyworks=Plut.01.56 (last accessed 13/04/2020).

30 Yerevan, Matenadaran MS 2374 (formerly Etchmiadzin MS 229): Macler 1920.

31 Recent scholarship has argued that the illustrated pages of the Rabbula Gospels were bound into the book at a later date and do not necessarily belong together with the main text (completed in 586). They may be earlier-from the first half of the sixth century and indeed the canon tables and the full-page miniatures may be from different sources and of different dates. See Bernabò 2008a, 16-21 and Bernabò 2014. There are significant problems also with later overpainting of the Rabbula miniatures: see Bernabò 2008a, 5 and Bernabò 2008b, with ad hoc discussion of each folio. Likewise Sirapie der Nersessian argued that the two leaves with four impressive full-page illuminations of narrative themes from the Bible bound in at the end of the Etchmiadzin Gospels (fols 228 and 229) are by a very different hand from those of the preface and may well have originally belonged to an entirely different and perhaps much earlier manuscript, perhaps sixth or seventh century, der Nersessian 1973. tament narratives (alongside commentaries from the Prophets) alongside the full page miniatures of the trial of Christ that are part of the opening display of the Rossano Gospels (fols 1r-8v). ${ }^{32}$ By contrast, the ecphrases and painted imagery of architecture create a different texture of inception-a kind of portal or threshold that signals the constructed monumentality of the edifice made of sewn parchment into which the reader is being initiated. ${ }^{33}$ The ecphrases anticipate, as we shall see, the arches that include titles or dedications as well as the Eusebian arcades of the codex tradition. Do any of these descriptive models reflect or play on actual but now lost prefatory pictures at the heads of ancient codices or even rolls?

We have no surviving frontispiece images from a papyrus book-although there are papyrus fragments with all sorts of drawings and paintings, ${ }^{34}$ including one striking architectural drawing that was found in Oxyrhynchus. ${ }^{35}$ But notably a number of major Carolingian luxury copies of prize late antique codices have impressive illustrated front matter that includes aedicules and arcades framing varieties of synoptic material including lists of texts, just as in the canon tables. In the Vatican Terence (Vat. lat. 3868) ${ }^{36}$ an author portrait in a square framed imago clipeata (fol. 2r, Fig. 4) is followed by a fine aedicule flanked by coloured columns with torus mouldings and delicately traced flutes, containing shelves holding theatrical masks (fol. 3r, Fig. 5). This is a prefatory image for the play that follows, the Andria, ${ }^{37}$ but in being placed immediately after the author portrait and in not carrying a label it serves effectively as a second architectural preface for the book as a whole. Uniquely, for a Carolingian miniature, this page is signed (illegibly in reproductions): MISERERE MEI DS [Deus] SE [cundum magnam miserecordiam tuam, $=$ Ps. 50.1]. ADELRICUS ME FECIT, ${ }^{38}$ again plausibly a claim for its general prefatory significance.

32 Rossano, Cathedral Library. Muñoz 1907 and Cavallo/Gribomont/ Loerke 1987.

33 For the vision of the Psalter as a house of many rooms, each with its own key and with the first Psalm as the door to the whole, see Jerome, Tractatus in Librum Psalmorum 1.1, with Pelltari 2014, 45.

34 A good selection of images from illustrated papyri may be found in Gallazzi/Settis (eds) 2006, esp. 45-53, 142-155, 277-281, 114-297 (the last a Christian scene); also Whitehouse 2016; Torallas Tovar/ Worp 2006, 17, inv. 154, pl. xxviii. The major collection of material from Oxyrhynchus remains unpublished.

35 See Whitehouse 2007, 296-306.

36 https://digi.vatlib.it/view/MSS_Vat.lat.3868 (last accessed 13/04/ 2020), with e.g. Koehler/Mütherich 1971, 74-75, 85-100 and Keefe 2015, no. 46.

37 So Jones/Morey 1931, 32; Koehler/Mütherich 1971, 89-90; Wright 2006, 8.

38 See Jones/Morey 1931, 33; Wright 2006, 8. 
That this set of forms belongs to the late antique prototype of this manuscript is certain: ${ }^{39}$ they appear in the same order in the pen-drawn versions of another C9 manuscript, Parisinus 7899 (Fig. 6). ${ }^{40}$ The aedicule with shelved masks is then a repeated frontispiece motif for different plays within the collection-marking the incipits of Heauton Timoumenos (fol. 35r), Adelphoe (fol. 50v), Hecyra (fol. 65r) and Phormio (fol. 77r). Now there is little doubt that these aedicules are prefatory in function and there is the possibility (unprovable of course) that they represent forms which ante-date the fourth century collection of the six plays of Terence into a single codex (the presumed prototype of these ninth century versions) and may have appeared in the papyrus rolls of individual plays. Note that the Terentian aedicules are either arched, as is most common in the canon tables (Heauton Timorumenos, Adelphoe and Phormio) or have a triangular pediment (Andria, Hecyra) ${ }^{41}$. While most canon tables are arched, some early manuscripts collected by Nordenfalk have Eusebius' canons with triangular pediments, ${ }^{42}$ so the forms of the Terentian prefaces have further weight as potential exemplars.

The seventeenth century copy of the lost ninth century copy of the lost lavish manuscript of the Codex Calendar of 354 (MS Barberini lat. 2154) ${ }^{43}$ certainly represents the design of an original codex creation of the fourth century. This has an impressive architectural image in its front matter for the natales caesarum page with an arcade of two arched openings on a spiral column between two jewelled columns supporting an arched entablature with an imperial bust carrying a globe with a phoenix in the tympanum flanked by winged victories (Fig. 7). The structure is very reminiscent of the architectural form of Eusebian canon

39 For an attempt to construct the prototype, which he dates to about 400 or a touch later in Rome, see Wright 2006, esp. 206-224. 40 See Paris, BNF, MS lat. 7899, fols 2r and v: https://gallica.bnf.fr/ ark:/12148/btv1b84525513 (last accessed 13/04/2020). There are later versions in two further illustrated Terence manuscripts: Basilicanus H.19 in the Vatican (tenth century), fols $9 \mathrm{v}$ and 10, and Bodleian Auct. F. 2.13 in Oxford (twelfth century), fols $2 \mathrm{v}$ and 3.

41 The prefatory aedicule for Eunuchus appears to have been lost in the exemplar and thus never copied in the ninth-century versions, see Wright 2006, 31, 206.

42 See Nordenfalk 1938, II, taf. 44: Vienna, National Library, cod. 847 (sixth century); taf. 162-3: Aachen gospel book (ninth century); taf. 165: Manchester, Rylands lat. MS 10 (tenth century); taf. 167: Cologne Cathedral, cod. 12 (tenth-eleventh century); taf. 168: Paris, BNF, MS lat. 17968 (ninth century).

43 See esp. Salzman 1990 with Burgess 2012. Usefully available online as http://www.tertullian.org/fathers/index.htm\#Chronography_ of_354 (last accessed 13/04/2020). On the seventeenth century copies, see Claridge/Herklotz 2012, 43-50, 94-126. tables, in this case with only two intercolumniations filled with written lists. ${ }^{44}$ This page is followed by similar framing architectures for the seven planets that represent the days of the week, again with space for written lists, as well as the representations of the months, again within architectural frames (of which only February, March, and then August to December survive) and between the images of days and the months, the two consular portraits of the Augustus Constantius II and the Caesar Gallus within curtained aedicules. The fine pen-drawn author-portrait of a bearded figure with an open scroll in an aedicule with triangular pediment and shell design from the Codex Arcerianus (fol. 67v, Fig. 8), a fifth- or sixth-century version of the Roman Corpus Agrimensorum, was painted as frontispiece to the collected florilegia of Agennius Urbicus, of whom the figure may be intended as a portrait. This may itself reflect a fourth-century prototype of the prefatory aedicule and is our earliest combination of the prefatory visual types of architecture and author. ${ }^{45}$

Among early Christian gospels, the prefacing of Eusebius's Letter to Carpianus followed by the canon tables is normal from our earliest manuscripts. Among these, the most sensational recent discovery is the group of old Ethiopic (or Ge'ez) gospels belonging to the Monastery of Abba Garima near Aksum in Ethiopia, which were first mentioned in the scholarly literature in $1960,{ }^{46}$ but became news after early carbon dates were reported in $2000 .{ }^{47}$ Crucially for our purposes here all three manuscripts have a rich range of illuminated canon tables at the front, with architectural arcades in Garima I, II and III, further images of buildings in Garima I and III, and the addition of portraits of saints in Garima III, all placed at prefatory junctures.

Two of the greatest early Christian gospels-the sixth-century Rossano Gospels, written in Greek, and the Syriac Rabbula Gospels, whose written text is dated by a colophon to 586 (on fol. 291r)-have all their rich illuminated pages bound at the front of the book before the start of the main text as a kind of prefatory pictorial précis of the contents. Both manuscripts have been mucked about in their long histories, their images likely having been rear-

44 Nordenfalk 1938, 117-120 rightly sees this page as ancestral to the Eusebian tables-as well as a number of non-prefatory astronomical tables that probably antedate the Eusebian canons but may first have appeared in arcade form in fourth-century codices, as replicated in the Vatican Ptolemy (Vat. gr. 1291).

45 See Carder 1978, 130-136, 198-201; Butzmann 1970, 28-30, 42-43. 46 Leroy 1960.

47 Mercier 2000. For a review of the history of scholarship see McKenzie/Watson 2016, 31-41. See the appendix to this paper for further discussion. 
ranged and several have probably been lost (especially in the Rossano Codex). But it is probable that all the miniatures were placed together as a visual set of frontispieces. Like the Garima gospels, this prefatory material includes the letter from Eusebius to Carpianus, and the Eusebian canon tables with their characteristic architectural arcade layout, in the case of the Rabbula Gospels (Figs 9a and b); it probably did so with the Rossano manuscript, but in this case they are now lost. However, in both these lavish products (and unlike the Garima manuscripts) there was additionally much illustrative material that visualised the narratives of the New Testament in pictorial form as a kind of preface or summary before the text itself. In the Rabbula Gospels these images occupied marginal positions within the pages with the canon tables, as well as several fullpage illuminations (which may or may not have been bound in later from a different manuscript altogether). In the Rossano Gospels these scenes were combined with commentarial images of the prophets and with Old Testament extracts foretelling the New Testament narratives of the main picture (which together filled a whole page and not just its margins).

The Garima Gospels avoid all this kind of complex commentarial interplay between word and image, illustration and scriptural text. On the other hand, Garima III -with its portraits of the evangelists as subsidiary frontispiece to each gospel in addition to the main run of prefatory images-is structurally very similar to the Rossano Gospels, which did the same thing, although there only the image of Saint Mark survives (fol. 12r). One might add that the architectural imagery for general preface and a specific author portrait for a given book reverses the late antique pattern of the illustrated Terence manuscripts which have one author portrait for the whole codex and architectural frontispieces in the form of aedicula for each play.

Other kinds of Christian manuscripts also made use of architectural prefacing. Consider the title page miniature of the Ashburnham Pentateuch (fol 2r, Fig. 10), which is probably a sixth century codex made in Italy, or at any rate in the West, and written in Latin. ${ }^{48}$ The title page shows an arch over a pair of double columns with bases and capitals, which has a decorative floral design and a large white figure resembling a conch shell in the tympanum; birds appear at either side above the arch. Purple curtains are attached to a rail beneath the tympanum, drawn open to

48 For the manuscript see Paris, BNF, MS Nouv. acq. lat. 2334 with von Gebhardt 1883 and the fine digitised facsimile at https://gallica.bnf.fr/ark:/12148/btv1b53019392c (last accessed 13/04/2020); also Sörries 1993, 26-33. On this page see Rickert 1986, 32-92 and Verkerk 2004, 125-183. reveal a square with a red-rimmed blue frame containing the titles of the books of the Pentateuch, written in fine rustic capitals in both Latin and a Latin transliteration of the Hebrew original. It does not show great ingenuity to see the comparison of this formal layout with the canon tables of Garima I, in particular, which have curtains (pink-purple in the case of McKenzie/Watson 2016, plate 40) and the interesting empty frame arch without curtains but with a conch shell in the tympanum (McKenzie/ Watson 2016, plate 41, see Fig. 23).

The architectural emphasis is true also of another major early manuscript from the West-the Codex Amiatinus, a complete Bible, which was written and illuminated in the late seventh century at Jarrow and is now in Florence. ${ }^{49}$ The dedication page at the very front (fol 1v) is, like the title page of the Ashburnham Pentateuch, an arch containing an inscription (Fig. 11), and there is also a purple leaf with the prologue and contents of the manuscript in a canon table-like arch form. Again, both for the manuscript as a whole and for the New Testament, forms of architectural imagery including arches on columns, canon tables and a temple-like enclosure, alongside an author portrait, constitute the book's visual frontage.

In an entirely different linguistic and even denominational context, the openings of a series of Syriac Biblical manuscripts surviving in fragments from between the sixth and eighth centuries use building forms to summarise chapter headings..$^{50}$ So a manuscript in London, BL, Add. MS 14445 (Fig. 12), dated to the sixth or seventh century, offers an architectural exordium in the form of a list of chapter headings presented within a grid beneath a series of arcades, in a pattern followed and elaborated upon by later Syriac manuscripts of the eighth century. ${ }^{51}$ Effectively these use the same pattern as the Ashburnham Pentateuch combining a series of prefatory précis in the form of headings or titles with an architectural mode of arrangement and disposition.

Finally, of broadly the same date as this range of parallels but from a different (and at the time radically new) religious tradition, we should note the significance of architectural prefacing in the oldest surviving manuscripts of the Qur'ān. The rediscovery of groups of stunning rare fragments from caches in the mosques of Amr

49 Florence, Laurentian Library, cod. Amiatino 1: See digital facsimile at http://mss.bmlonline.it/s.aspx?Id=AWOS3h2-I1A4r7GxMdaR\#/ book (last accessed 13/04/2020). There is a large literature. See e.g. Bruce-Mitford 1967; Corsano 987; Meyvaert 1996; Nees 1999, 148-176; Chazelle 2003; Gameson 2018, with bibliography.

50 See Leroy 1964, 124-125.

51 Including the manuscripts London, BL, Add. MSS 12134 and 14429 (fol. 3r); also Paris, BNF, MS 97 (fols 92r and 92v). 
ibn-el-as (Fusțāț, Cairo, Egypt), Damascus and Șan'â' (Yemen) are transforming our understanding of the early Qur'ān and the relation of its texts to illumination. ${ }^{52}$ Notably, the Umayyad Qur'ān of Șan'ā' (itself not very far from Ethiopia across the Red Sea), dated by radiocarbon and chemical testing to between 657 and $730 \mathrm{CE},{ }^{53}$ opened with an architectural circle framed by a double square in the form of an eight pointed star with trees bearing fruit -which may have been intended to evoke a centrifugal architectural plan (like the Dome of the Rock). This page proceeded a double spread of spectacular, beautifully illuminated architectural illustrations with round arches and vegetal motifs that look very much like idealised mosques (including minbar and mihrab), both also with trees (e.g. Fig. 13). ${ }^{54}$ Meanwhile, the early Qur'ān known as 'Marcel 13' from Fusțāt, but perhaps made in Syria in the early eighth century, now in the National Library in St Petersburg, as well as a number of other early Qur'ānic manuscripts, ${ }^{55}$ uses various forms of decoration but notably columns lying on their sides to mark the beginnings of various suras (or chapters) within the main text (Fig. 14). ${ }^{56}$ In all these cases, architectural prefacing through illustration is key both at the inception of the manuscript as a whole (in the case of Șan'â') and at the beginnings of chapters. In the remarkable Șan'â' codex this is a clear parallel to, and perhaps even deliberately competitive with, Christian and potentially Jewish illuminated depictions of the temple. ${ }^{57}$

\section{Portraits}

Two early types of author portraits-the bust (usually in an imago clipeata, such as we have already seen for Terence, Fig. 4) and the group portrait for volumes that gather the collective knowledge of several scholarly authors-appear not to have survived long beyond Antiquity. It is possible

52 For general accounts see George 2010, 74-89; Flood 2012, 265-277. 53 See George 2010, 79.

54 See von Bothmer 1986; von Bothmer 1987a; von Bothmer 1987b, 178-181; Grabar 1992, 155-193; Flood 2001, 63-65.

55 These include Paris, BNF, MSS arabe 324c and 330c and Istanbul, Türk ve İslam Eserleri Müzesi, ŞE, 321.

56 See F. Déroche 2004, 244-248; Flood 2012, 270-271; F. Déroche 2014, 89-91.

57 At least one major carpet page from a Jewish manuscript, originally found in Egypt, depicting the temple survives from the tenth century (National Library, St Petersburg Hebrew II B 49). It is not clear where it stood within the original manuscript nor how it might have related to an earlier tradition, but it is tantalising. See Schwartz and Fine 2012, 114 (catalogue no. 76). that our earliest surviving imago clipeata at the inception of a book is the sheet (of different parchment from the rest of the book, which is probably a copy of an archetype of about $450 \mathrm{CE})^{58}$ bound into the ninth century Palatine Agrimensores, in the Vatican Library, a florilegium of texts about land surveying (Fig. 15)..$^{59}$ The sheer oddity of this page is worth stressing. It contains a painted medallion portrait of a youthful, clean-shaven man above a sketched portrait of a balding and bearded man, in very similar postures and dress. Is one a later product emulating the other? There is no reason that they must be contemporary, but neither represents the style of the other group images -which include two pages with nine men in discussion (fols 2r and 3r) plus one of an adjudicator or judge and an emperor (fol. 4r) which are all probably Carolingian, but may be frontispiece group portraits for a multi-author collected volume. The pattern resembles the splay of frontispieces of the Vienna Dioscorides, a manuscript of about 512 painted at the behest of the wealthy Constantinopolitan aristocrat Anicia Juliana, which is also a florilegium of pharmacology by ancient savants. ${ }^{60}$ Here two images of seven physicians each (fols $2 \mathrm{v}$ and $3 \mathrm{v}$ ) precede two pages of single author portraits-Dioscorides inspired by the personification of Heuresis (fol. 4v) and Dioscorides writing his text accompanied by a draughtsman and by the personification of Epinoia (fol. 5v, Fig. 16). These themselves precede the book's donor portrait (fol. 6v) and title page (fol. $7 \mathrm{v}$ ), both in imagines clipeatae. The shared prefatory pattern of the Vatican and Vienna manuscripts is intriguing: Numbers of group images and two single author portraits, although in the Vienna Dioscorides the authors follow the groups while they precede them and occupy a single page in the Palatine Agrimensores.

Of the Garima manuscripts, only Garima III has author portraits (in addition to architectural forms), also functioning as frontispieces. ${ }^{61}$ The first-tentatively identified as 'Eusebius' by McKenzie and Watson-which appears before his Letter to Carpianus, is in fact the first miniature surviving from that book (Fig. 17). It follows the

\section{See Thulin 1911, 5.}

59 Pal. Lat. 1564, fol. 1. See Thulin 1911, 46-48; Mütherich 1974; Haffner 1991, 136-138; Palm 1997, 168-173, where a sixth to seventh century date is suggested.

60 Codex Medicus Graecus 1, Austrian National Library: See Mazal 1998-1999.

61 The standard discussion of evangelist portraits is Friend 1927 and 1929. There (at 1927, 24) Friend identifies standing and seated types as the two normative iconographic models. There have been many studies since, notably Wessel 1968-1969 and Loerke 1995. For the Garima portraits see now Mathews 2016, 359-63, 367 (proposing that the standing evangelist portraits and 'Eusebius' depict the liturgical showing of the gospel). 
prefatory text of the argument of the four gospels and it is not inconceivable that an earlier title page miniature, perhaps architectural, was placed at the very front. ${ }^{62}$ The image of 'Eusebius', like the portraits of Matthew, Luke and John, shows a standing saint holding a gospel book in his left hand (the evangelists' codices are square with crosses on the front, 'Eusebius' holds a more oblong book with zigzag binding, and while they stand on footstools he does not). Each of these figures makes a gesture of blessing with his right hand and all have halos (Fig. 18). Mark, in classical dress but with a bishop's scarf, is seated before a lectern in the shape of a dolphin and blesses with his right hand the book that rests on it (Fig. 19). The seated type of author portrait is the most common-one thinks of the images of Vergil at the openings of Eclogues 2, 4 and 6 in the fifth- or sixth-century manuscript known as the Roman Vergil (Fig. 20), ${ }^{63}$ of the fifth- or sixth-century seated author portrait within an aedicule at fol. $67 \mathrm{v}$ of the codex Arcerianus of the Roman Corpus agrimensorum (see Fig. 8), ${ }^{64}$ the two images of Dioscorides in the Vienna Dioscorides (fols $4 \mathrm{v}$ and 5v, see Fig. 16), the great Luke miniature of the sixth century Augustine Gospels (fol. $129 \mathrm{v}$ ), ${ }^{65}$ the surviving portrait of Ezra in the codex Amiatinus (fol. 5v), ${ }^{66}$ and the St Mark illumination of the Rossano Gospels (fol. 121r). The seated and standing types are combined on facing pages of the Rabbula Gospels (fol. $9 \mathrm{v}$ and 10r) in the marginal illustrations of canons 7 and 8, where Matthew and John without halos (fol. $9 \mathrm{v}$ ) are seated while Mark and Luke with halos are standing with square books that have crosses on their covers (see Figs $9 \mathrm{a}$ and $9 \mathrm{~b}) .{ }^{67}$ The model of a single miniature at the head of each book of an entire Bible-of which most miniatures are portraits and many are in the standing and blessing posture of standing evangelists of Garima III-is offered by the sixth or early seventh century Syriac Bible in Paris, known as Syr. 341, where most of the New Testament is unfortunately missing. In this iconographic form with scroll rather than book, we find images of James the apostle at the head of his letter, fol. 248r, and the prophets Haggai (181v), Habbakuk (180v, Fig. 21), Michah (179r),

62 Like those of the Ashburnham Pentateuch and Codex Amiatinus. 63 BAV, MS Vat. Lat. 3867, fols 3v, 9r, 14v with Wright 2001.

64 See Butzmann 1970, 28-30, 42-43.

65 Cambridge, Corpus Christi College, Parker Library, MS 286, fol. 129v: see Wormald 1954, 2-3, 5-11. One might note in passing that the Christian tradition appears not to have preserved the imago clipeata model of author portrait, as for example in the lost late antique manuscript of Terence, copied in the ninth century and now in Vatican City, BAV, Vat. Lat. 3868, fol. 2r with Wright 2006, 6-7. 66 E.g. Corsano 1987, 15-22; Marsden 1996; DeGregorio 2010. 67 E.g. Leroy 1964, 148.
Obadiah (178r) and Joel (175r). ${ }^{68}$ This pattern is at least suggestive for the structure of Garima III.

One striking Syriac book of the sixth century, much of it unfortunately lost, is the Syriac manuscript at the Syrian Orthodox Church of Mar Jacob of Sarūg in Diyarbakır, south-eastern Turkey. ${ }^{69}$ The prefatory visual material however survives complete. ${ }^{70}$ The manuscript has relatively simple canon tables with marginal birds, plants and baskets of fruit in a tradition close to a number of other sixth/seventh-century Syriac manuscripts. Before the canon tables (fols $2 \mathrm{v}-10 \mathrm{v}$ ) was the letter of Eusebius in architectural tables topped with four arches (1v- $-2 \mathrm{r})$. Before this, as the opening miniature, was a striking image-either of Christ or of John the Evangelist, in a golden halo standing in a roundel with a geometric pattern at its rim, wearing a purple robe, holding a book inscribed with the beginning of St John's gospel, and making a blessing gesture between two cypress trees (fol 1r, Fig. 22). It is natural of course to show Christ in this position at the start of the gospels, ${ }^{71}$ and would be weird to show John, when the written work that follows is Matthew-but the text on the illustrated book is the opening of the fourth gospel, and so the option cannot be discounted in the absence of further identifying marks or a cruciform halo. The similarity of position, posture and iconography to the standing saints of Garima III makes one wonder if an exemplar like this had been understood by the Ethiopian artist to be a typical saint's portrait, and thus interpreted as Eusebius. But by contrast with all these various comparisons, the standing portraits of Garima III are framed icons of the saints on plain backgrounds that directly address the viewer. They are a strong affirmation of the cult of images, all the more so for being painted into holy Scripture.

\section{Conclusion}

I have attempted to show something of the interface of different kinds of prefatory imagery for book collections dating back to pre-Christian Antiquity-the architectural frontispiece, which becomes the Eusebian canon tables

68 Sörries 1991, 41-44, 49-50.

69 MS 339: see Leroy 1957, 119-124; Leroy 1964, 207-208; Bernabò/ Kessel 2016.

70 It is not impossible that this material belongs to a different original book from the one in which it is currently bound and was added later. See Bernabò/Kessel 2016, 176 and 183.

71 Cf. Christ in Majesty (admittedly surrounded by the four Evangelists in the page's corners) in the Codex Amiatinus, fol. 796v, at the inception of the Gospels. 
in gospel manuscripts as well as forming one model for the title, dedication or contents page; the author portrait, which is the origin for the classic evangelist images; and the pictorial vignette as précis for a larger narrative. We may wonder if these prefatory visual strategies seek to reveal different aspects of the written work that follows: the human touch behind the text of any given book-its authorship and speaking voice, in the case of author portraits; a visualisation of the threshold and the concomitant spatial exploration which entering a book constitutes for a reader as she or he traverses the pages, in the case of arches and arcades (which establishes the codex as a kind of edifice or monument); an anticipatory hint of the text's drama (like a trailer in the modern cinema or television series) in the case of narrative vignettes. The architectural image in particular focalises the artefactual nature of the book as something constructed of parchment or papyrus, carefully treated, rolled or stitched, inscribed and painted on.

In a sense, each kind of prefatory image is a different sort of synopsis of the contents. The authorial portrait -whether of a secular writer, an evangelist, of Eusebius or of Jesus as the Logos of the Gospel-sums up the text through a form of personification, itself one of the most ancient tropes of visual and rhetorical representation, but specifically focalised as the personification of the book's creator's authorial voice. The narrative summary as picture both prefigures the literary account that will follow and renders it in a different, visual, medium to be seen in a single glance rather than read diachronically as the pages turn. Its shift of media from the written to the painted is also a shift of temporalities from the reading process to the synoptic glance, both these models operating within a visual regime. The aedicule or arcade, containing titles (as in the Ashburnham Pentateuch and the Syriac manuscripts) or masks representing speaking voices (as in the Terence manuscripts) or a dedication (as in Codex Amiatinus) or a prefatory text (as in the Letter to Carpianus) or a range of parallels between the gospels which ultimately serve as a kind of shorthand or summary of their collective content (as in the Eusebian canon tables), sums up the text by literally containing it as formulated as a kind of précis in most of these cases through a list. What is certainly the case is that the Eusebian model added a spectacular level of complexity and scholarly depth to the architectural prefatory pattern: Ten tables with 'the particular passages in each Evangelist where they were moved by love for the truth to speak about the same things' (as Eusebius puts it in the Letter to Carpianus) ${ }^{72}$ and a

72 From the translation in Crawford 2019, appendix 1, p. 295. preface to this preface in the letter itself. One of the outstanding developments of the early codex is a high level of sophistication in playing through these kinds of synopsis -scholarly list as architecture, pictorial narrative summary and author-portrait-through the frontispieces, and indeed of combining them. This is already apparent in the lost archetype of the illuminated Terence manuscripts, where the author's portrait heads the whole collection but individual aedicules containing masks that represent the characters in a given play are used as the visual prefatory introduction for each of the plays. But it reaches high levels of artistry in the early Christian gospel book-not only in the art of illumination but also in the use of images and paratexts to structure a text and help its readership.

The issues are much more complex and subtle than Kurt Weitzmann's literalist and reductive arguments more than half a century ago about the putative move of images on rolls to the illustration of codices, ${ }^{73}$ or than the claims for the relationship between manuscript illumination and large-scale painting. ${ }^{74}$ They involve a continuous and revolving dialogue of image and text in which (perhaps imagined) paintings are rendered descriptively as ecphrasis in the introductions to ancient novels and declamations, texts are focalised as images (whether through narrative summaries or author portraits) in a host of late Classical and early Christian manuscripts, and images themselves come to inspire exegetic descriptions in the medieval Irish and Armenian discourses on the canon tables. The emerging culture of the codex effectively creates through its early development what has been called an 'ecphrastic circle' whereby image is rendered as text and text as image in a continuing intermedial dialogue. ${ }^{75}$ The resources created by this process are rich. For example, once author portraits are repeated, a number of different messages may be communicated. The repeated portrait at the heads of the evenly numbered Eclogues in the Roman Vergil is a reiteration of authorship that may be a gesture in response to any doubts about authenticity ${ }^{76}$ or an evocation of the supposedly autobiographical nature of these poems from a late antique perspective; ${ }^{77}$ the multiple evangelists in a gospel book, looking alike but different, are a powerful claim for four as one and for the unity of the gospel in its diversity; the single Terence at the front of the lost late antique exemplar of the ninth

73 E.g. Weitzmann 1947; Weitzmann 1959. For critique see e.g. Squire 2009, 122-139 and Squire 2011, 127-139.

74 E.g. Loerke 1961 or Kessler/Weitzmann 1990.

75 For the 'ecphrastic circle' see Squire 2011, 303-370.

76 On the problems of faking Vergil in Antiquity, see Peirano 2012, 74-116, 173-204, 242-253.

77 See Peirano 2012, 17, 61-62, 107-109. 
century illustrates Terence manuscripts are a statement of one voice through many plays. The experimentation of layouts-full-page illumination, smaller images aligned against text, marginal images-is itself part of the creativity enabled by the new form. In particular in the extended codex of written texts, even small pictorial insertions to mark breaks between sections-as in the columns between Suras in 'Marcel 13' or the small standing author portraits of the Syriac Bible in Paris (compare Figs 14 and 21)-define these points and these pages as distinctive. In part the flexibility involved derives from the 'ambidextrous' nature of the codex from its inception-laid out right to left for works in Hebrew, Syriac or Arabic, and left to right for works in Greek, Latin, Armenian or Ethiopic, for instance, but reversible when these languages were translated (for instance from Hebrew to Greek or Greek to Syriac). The inclusion of paratexts of all kinds within this paraphernalia was a further prefatory enrichment. By the time this process was mature, probably within the fourth century itself and certainly before the sixth, all the formal elements that have come to characterise the modern book, before the digital age, were already in place.

\section{Appendix: Reflections on the Garima Gospels}

It is striking how little we know about the Garima Gospels. $^{78}$ We have a published report only of the dimensions of Garima I-34 cm by $22 \mathrm{~cm} ; ;^{79}$ we have no precise measurements of the other two books. ${ }^{80}$ No one has tested the parchment toseeifit iscow's, goat's orsheep'sskin. Carbon-

78 First publication: Leroy 1960.

79 On the three different Gospel books included within what are known as the Garima Gospels, I follow McKenzie/Watson 2016, 3166. See also the review by Bausi 2017. For the size, see Leroy 1960, 132; Leroy 1968, 75; McKenzie/Watson 2016, 43.

80 Discussion is complicated by the fact that the three books were bound into two volumes in a haphazard order, which were incorrectly numbered in 1979 by Macomber 1979, 1-11 in an order that was significantly changed on rebinding in 2006. Digital versions of the Garima I and Garima III (but not Garima II) are available, if one gets an account, through the Hill Monastic Library: http://www.hmml. org/uploads/2/1/6/0/21603598/100190_sju_illuminations_rev5-26.pdf (photographed in 2013, in uncorrected electric light and not entirely restored to the correct order). Direct links are: Garima I, https://www. vhmml.org/readingRoom/view/132896 and Garima III, https://www. vhmml.org/readingRoom/view/132897 (last accessed 13/04/2020). The Hill Monastic Library gives a different measurement from Leroy for Garima I, i.e. $35.3 \times 26.4 \mathrm{~cm}$; and it also gives dimensions for Garima III of $33.2 \times 25.4 \mathrm{~cm}$. It is not clear how these were established or why the former differs from Leroy.
14 dates were supplied in 2000 for two illuminated pages from Garima III, offering the date range $330-650 .^{81}$ This is a conflation of the dates for the two folios-one of them (an evangelist, we are not told which) being 330-540, and the other (the page with the second half of the letter of Eusebius and the first canon table) being 430-650. A second test in 2012 on a different, unspecified, page offered the dates 390-570; at the same time in 2012, a single reading from a page of Garima I gave the dates 530 $660 .^{82}$ These results (if all are indeed correct) relate to the dating of the vellum; they do not tell us anything about the date of pigment, or of painting, or of writing, or of the production of the book. The current communis opinio on dating for the illuminations is converging on the early period (say the sixth or early seventh century) at least for Garima I and III. ${ }^{83}$

But we do not know if they were painted on fresh parchment or on parchment that had been stored, on parchment that had been imported (perhaps along with whatever models the artists used to create the exquisite visual decoration that survives today, or indeed with the front-matter fully painted and ready for writing, as potentially implied by the empty arch folio of Garima I which was prepared for text but never used, Fig. 23$)^{84}$ or on vellum that was locally produced, or a mixture of these. The visual parallels of Garima I and III are all with surviving Greek, Georgian and Armenian manuscripts from the ninth century and later (e.g. Fig. 24). ${ }^{85}$ This means-if we accept a sixth-seventh century dating for the decoration on relatively fresh parchment-they are the unique earliest surviving exemplars of a style of illumination that must have had some circulation before Byzantine Iconoclasm, of which no other examples have survived, and

81 Mercier 2000, 35-45, esp. p. 40; McKenzie/Watson 2016, 40-41. 82 Not scientifically published but reported in the media: See McKenzie/Watson 2016, 40-41.

83 See Heldman 1993, 129-130 ('sixth century date'); Mercier 2000, 45; McKenzie/Watson 2016, 40-41 ('a sixth to seventh century date might in fact be correct'). Earlier views (summarised by Leroy 1960, 132, 143 and Leroy 1968, 78) look towards the ninth to the eleventh century. For a lively account of many issues see Bausi 2011.

84 The arch on the recto of the tholos page is strange-an empty frame designed as if for a canon table but not used as such and indeed not used for anything. Although it resembles the other canon tables of the manuscript in its form and decoration (and especially Canon 7, the last of the tables, which has been reconstructed as its left hand opening, in the decoration of its arch bands, the articulation of columns and capitals and the birds above), the curtains that are drawn open in each of the canon tables of Garima I are absent from this arch, implying that second thoughts may have taken place before the decoration was complete.

85 See McKenzie/Watson 2016, 105-116. 
which was then frequently emulated across the east from the ninth century. Or-if we assume the possibility of long storage of parchment-they most likely belong with their post-Iconoclastic parallels. For reasons of expense, scholars are very reluctant to assume long-term storage of large quantities of vellum, but if the pages of Garima II (which is stylistically different and generally dated much later) were carbon-dated and found to be early, then the case for storage would need to be revisited. Note that even if we accept a date of, say, 630 for the making of Garima III (well within the carbon-dated range of the folio with the first canon table) then we would have to accept storage for 90 years and 60 years respectively, beyond their last possible date of production, for the two other pages of that manuscript so far tested. In the face of hard science but the absence of enough of it, conclusions on dating need to remain tentative.

A further issue is the extent to which the parchment may have been reused, its surfaces potentially scraped, as has been suggested for the Rabbula Gospels. ${ }^{86}$ This is impossible to determine from the photographs we have -it needs direct autopsy by experts. In the case of the tholos, which in the sequence of illuminated pages reconstructed by McKenzie and Watson for Garima I, appears as the last of its miniatures (Fig. 25), ${ }^{87}$ it does look as if there were at least second thoughts. One can clearly see, at the background of the roof structure of the tholos that the manuscript page was scratched with a number of concentric semicircles to form the upper part of an arch with several bands. These may represent the marking lines that were used to articulate the arch that appears on the recto of this page (Fig. 23);8 but it is quite possible that this page was itself prepared for an arch and the plan was changed. It is not inconceivable that the smudge above the top of the scratched arch on the right was once a bird of the kind that appears on all the canon tables of Garima I; or is it a stain from when the manuscript was once wet? The writing beneath it and under (?) the bird to the right may likewise be an imprint from something once facing this folio or it may be original to it (see Fig. 26A)... Further, one may wonder about the two baskets or bowls of fruit or purple flowers that appear above the tholos roof to the left and right (Fig. 26A). There are many baskets in the architectural pages of this manuscript (for instance at the

86 Bernabò 2014, 348.

87 McKenzie/Watson 2016, 46-48.

88 Note that the marking lines for the circle on the recto of the last decorated page of the prefatory miniatures of Garima III show through the pigment of the image of St Matthew at the head of his gospel on the verso, see McKenzie/Watson 2016, 52-54. apex of the arch in canon tables 1, 2, 5 and 6 (Fig 26B), and on the left and right at roughly the same position as in the tholos image in pages 2 and 3 of the letter of Eusebius, (Fig 26, i.e. Fig 26C). But none have this form, which looks as if it might have been the image of a capital adapted to becoming a fruit basket. Is it the line of what was once a column (overlapped by what is now a rather faded tree) reaching up to what was once the capital on the right, or is this the effect of staining (also visible on the recto of the page) that may have been the result of binding coupled with folds in the vellum? The case for the fruit baskets in fact having once been capitals seems strengthened by what appear to be contour lines of a column not coloured-in, running up towards the basket-capital, on the lefthand side as well as the right (Fig. 25). In any case, even if-in the absence of infrared or x-ray photography-we cannot construct what may have been beneath what we now see, the scoring and the writing are evidence of what may have been two earlier phases if not more.

Further, we may ask why the text of the second page of Eusebius's letter in Garima I is so closely crammed up to the columns on either side (Fig. 27). Was the painting added after the text? And if so, how much later? Likewise, in the canon tables of the same manuscript, the grid pattern was clearly designed before the arch and curtains were painted. On Canon 1, either the curtain was only half drawn or it was swiftly rubbed out (Fig. 28A); in Canon 2 it overlaps the text (Fig. 28B), after Canon 3 an accommodation has been reached with the curtains overlapping the grid but the text being adjusted (Fig. 28C). Again, on a number of pages of Garima III there seem to be ruled or scratched horizontal lines with no relation either to the grid pattern or the decoration or any text: the pages look as if they were prepared for something else beforehand (Fig. 29). Arguably, something similar may be said for the canon tables with canons 6-10 in Garima II, where there seems to be a lot of faded writing in a different colour ink beneath the current black ink (Fig. 30). ${ }^{89} \mathrm{I}$ am not sure how much further we can get with the current state of this manuscript and the current photographs that we have. Much more, and much more scientific work, would need to be done to ascertain with certainty whether this is in part a palimpsest. But the possibility that the tholos is a painting on top of an earlier stage is extremely suggestive for those who might worry that dates for the parchment should not determine dates for the workmanship.

A most important aspect of the Garima manuscripts is the fact that we have three. In no other early case do

89 McKenzie/Watson 2016, plates 49-52. 
we have so many illuminated manuscripts that are clearly interconnected and yet choose different visual strategies for their presentation. Garima I and II avoid portraiture and Garima III insists on it. On textual grounds it has been argued that neither Garima I nor Garima III were copied from the other, but that are both based on different exemplars probably derived from a common prototype, which is ultimately a translation from Greek made not later than the sixth century. ${ }^{90}$ The fine quality of the decorative work in the frames of the portraits in Garima III is sufficiently similar to the ornamentation of the arch bands in the canon tables of the same manuscript, to guarantee that the portraits belong with the rest of its decoration and were not added later. It may be that the inclusion of portraiture has no greater significance than the whim of a patron or a larger amount of money available for Garima III than for Garima I or II. But the presence and absence of images in the Ge'ez manuscripts may be Ethiopian evidence for the argument about aniconism (possibly extending to iconophobia and even to destruction) versus forms of image worship in the period before Byzantine Iconoclasm, which began about $730 \mathrm{CE}$ in Constantinople, ${ }^{91}$ but clearly had significant influence (at least ideologically and perhaps materially) across the whole of Christendom, including in the Miaphysite context of Armenia. The debates are well attested in the Eastern Mediterranean, in Syria and in Armenia for the sixth and seventh centuries. ${ }^{92}$ If the Garima manuscripts were to be ninth century or later, then they may be taking explicit and contradictory positions in relation to the most vibrant debate within the Christian community in the East (a conflict with significant ramifications at the time not only in Constantinople but as far as Damascus and Carolingian Court) or they may reflect manuscript exemplars that did so. ${ }^{93}$
91 For the outbreak of Iconoclasm and the many problems about it, see Brubaker/Haldon 2011, 79-94.

92 For some general discussion, see Kitzinger 1954; Baynes 1960; Cameron 1979; Barasch 1992; Besançon 2000, 11-146; Bremmer 2008; Elsner 2012 and essays in Campagnolo/Magdalino/Martiniani-Reber/ Rey 2015. On Armenia, see der Nersessian 1944-1945; der Nersessian 1946; Alexander 1955; van Esbroeck 2003; Mathews 2008/2009; Rapti 2015. On Hypatius of Ephesus, see e.g. Alexander 1952, 178-181; Grouillard 1961; Lange 1969, 44-60; Thümmel 1992, 103-106 and Gero 1975. On Leontius of Neapolis, see V. Déroche 1986; Lange 1969 621-676; Thümmel 1992, 127-136, 233-236 and V. Déroche 1994.

93 On Byzantine iconoclasm, see Grabar 1957; Barnard 1973; Bryer/ Herrin 1977; Brubaker/Haldon 2011. On the East, see Griffith 1997; Louth 2002, 193-222; Auzepy 2007, 209-57; Griffith 2008; and Codoñer 2013. On the West, see Auzepy 2007, 285-316; and Noble 2009. 

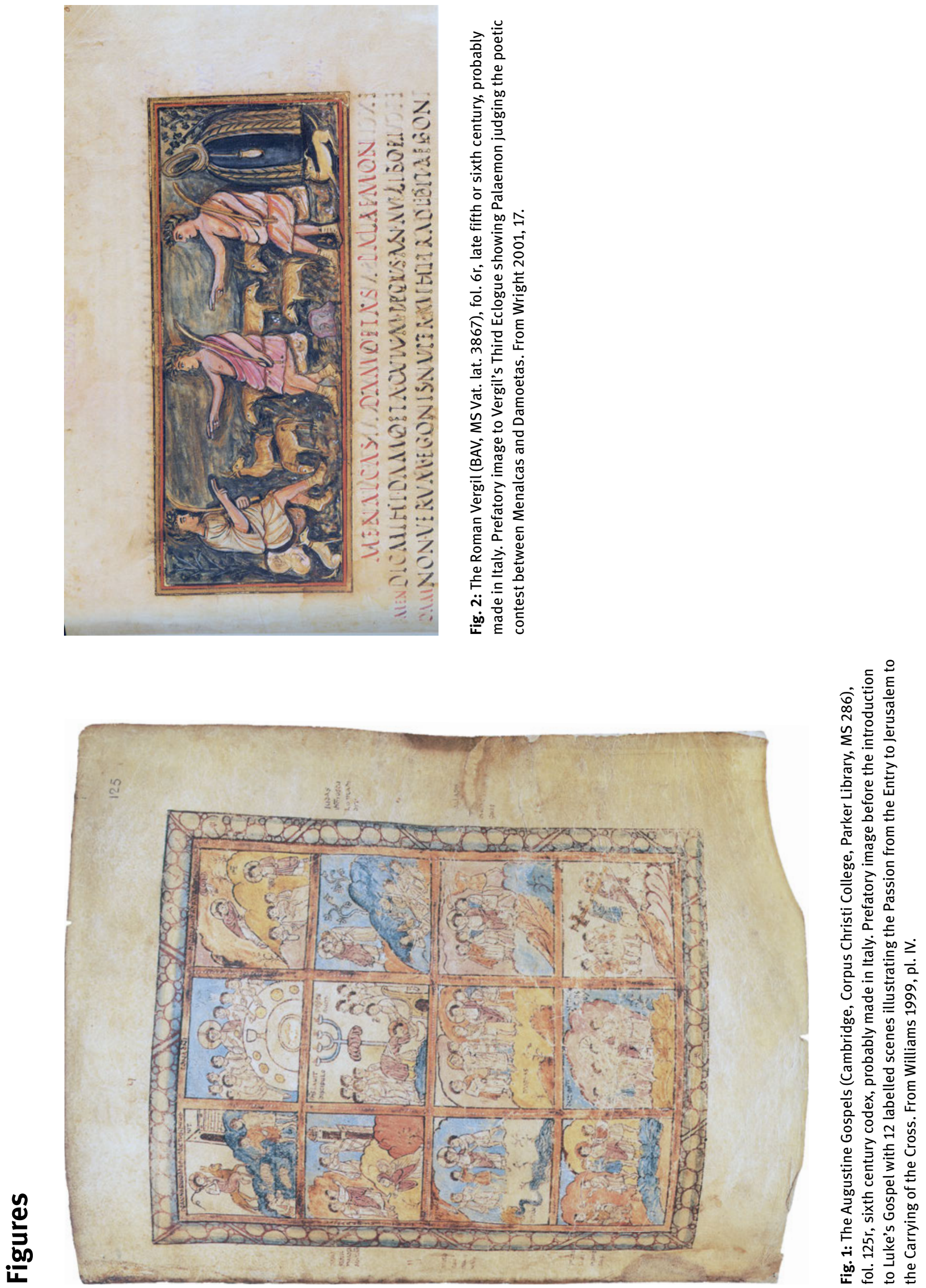

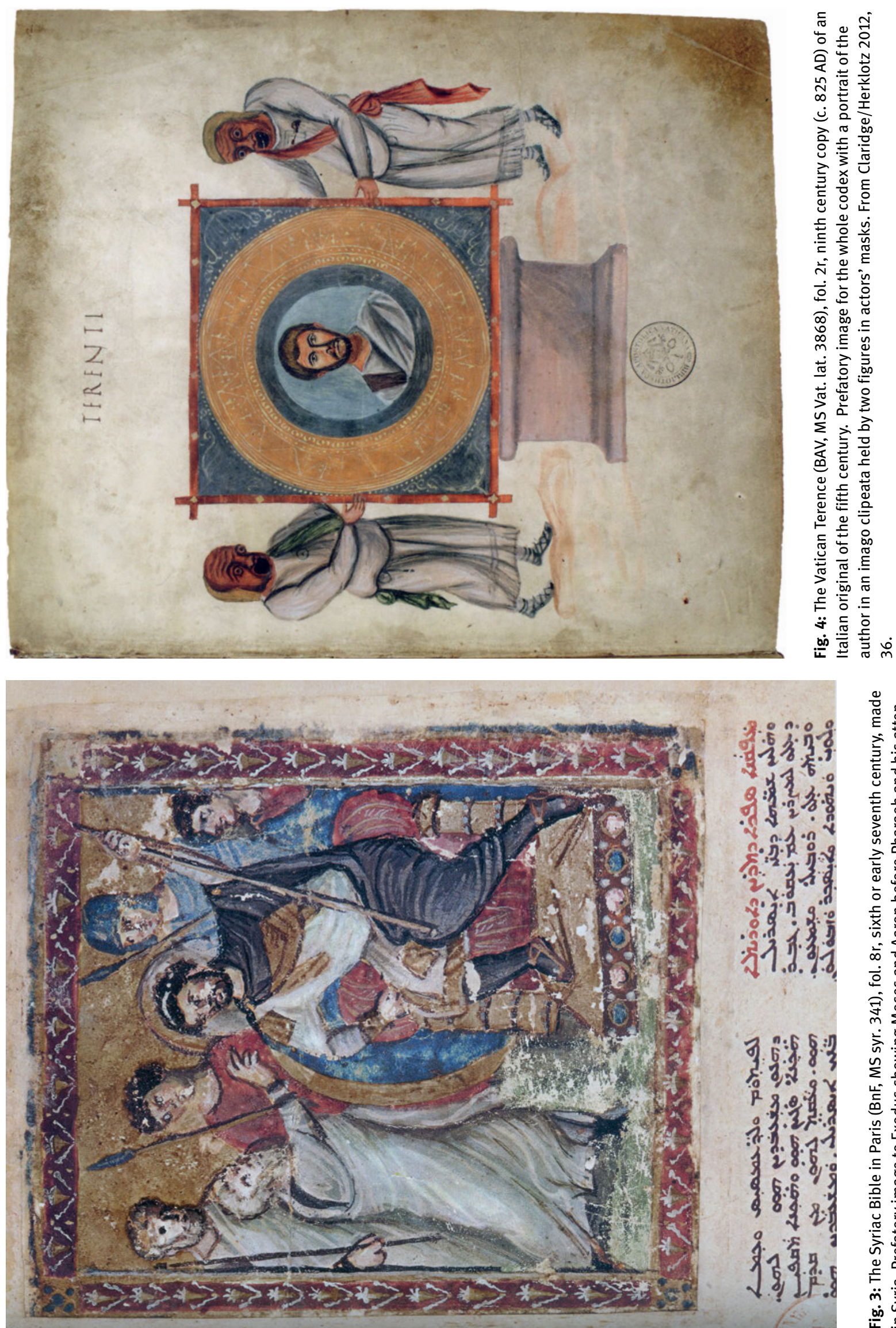

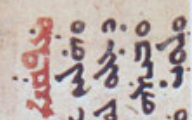

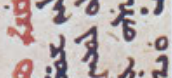

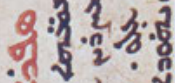
- 300 है. ง.ं. รู1 \%

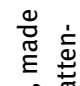
言管

당 들

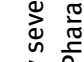

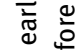
के

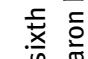
㐫 要 市 䚻

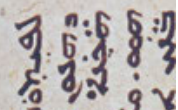
离 F.

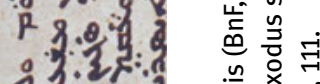
ใ. 38.5 .5 용

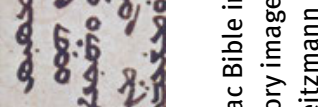
o 2 2.

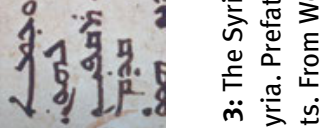
的党 

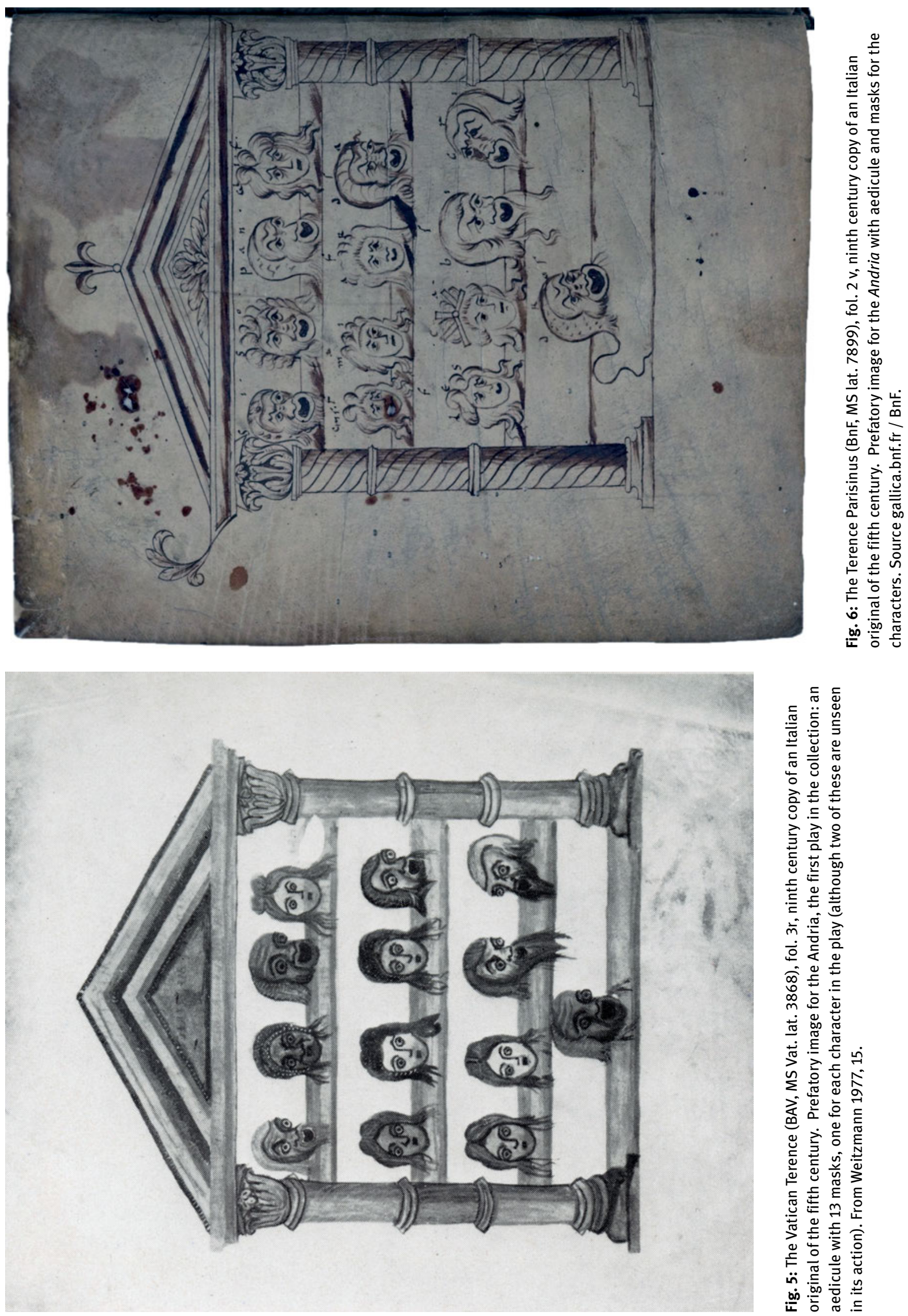

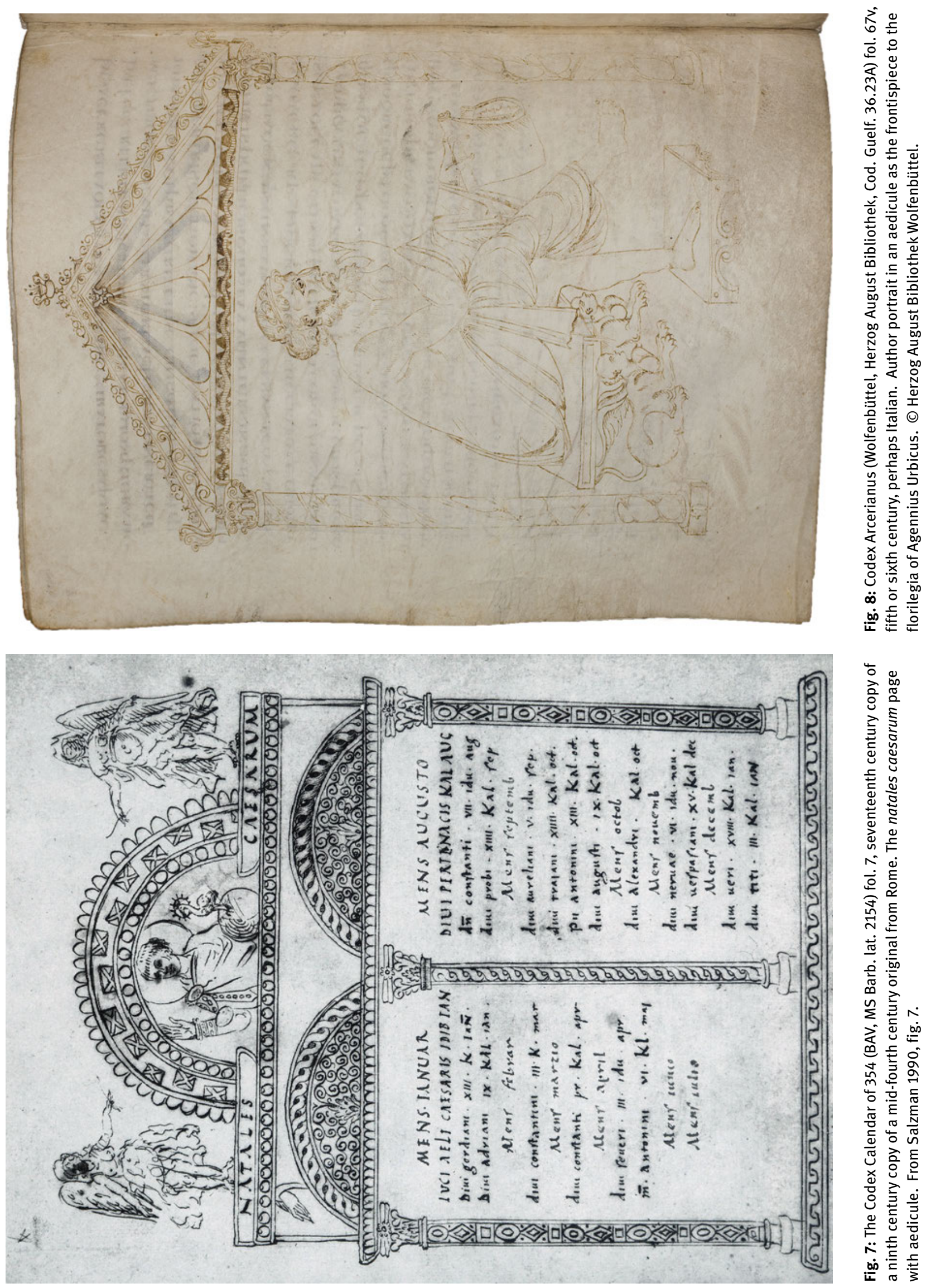

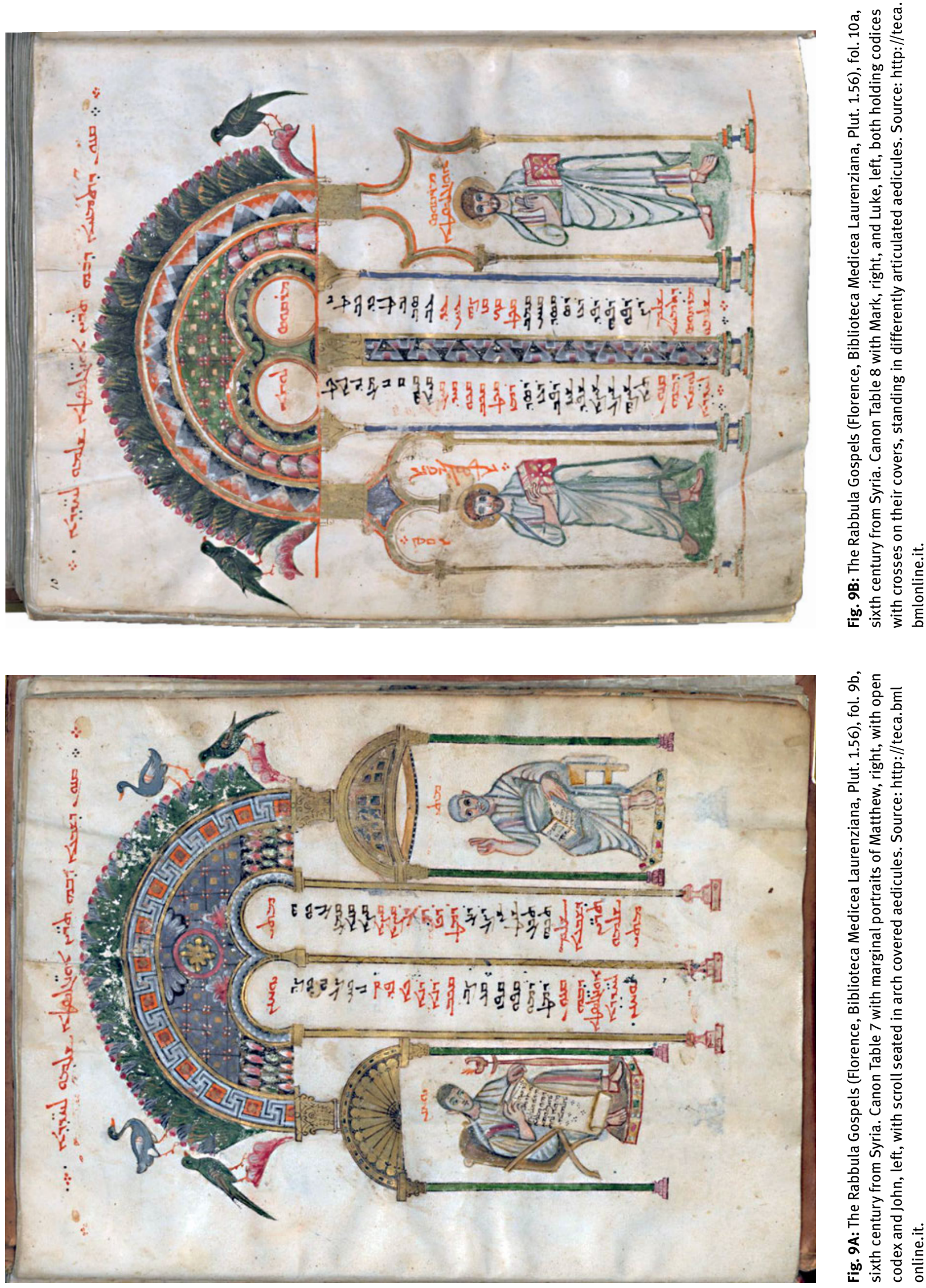

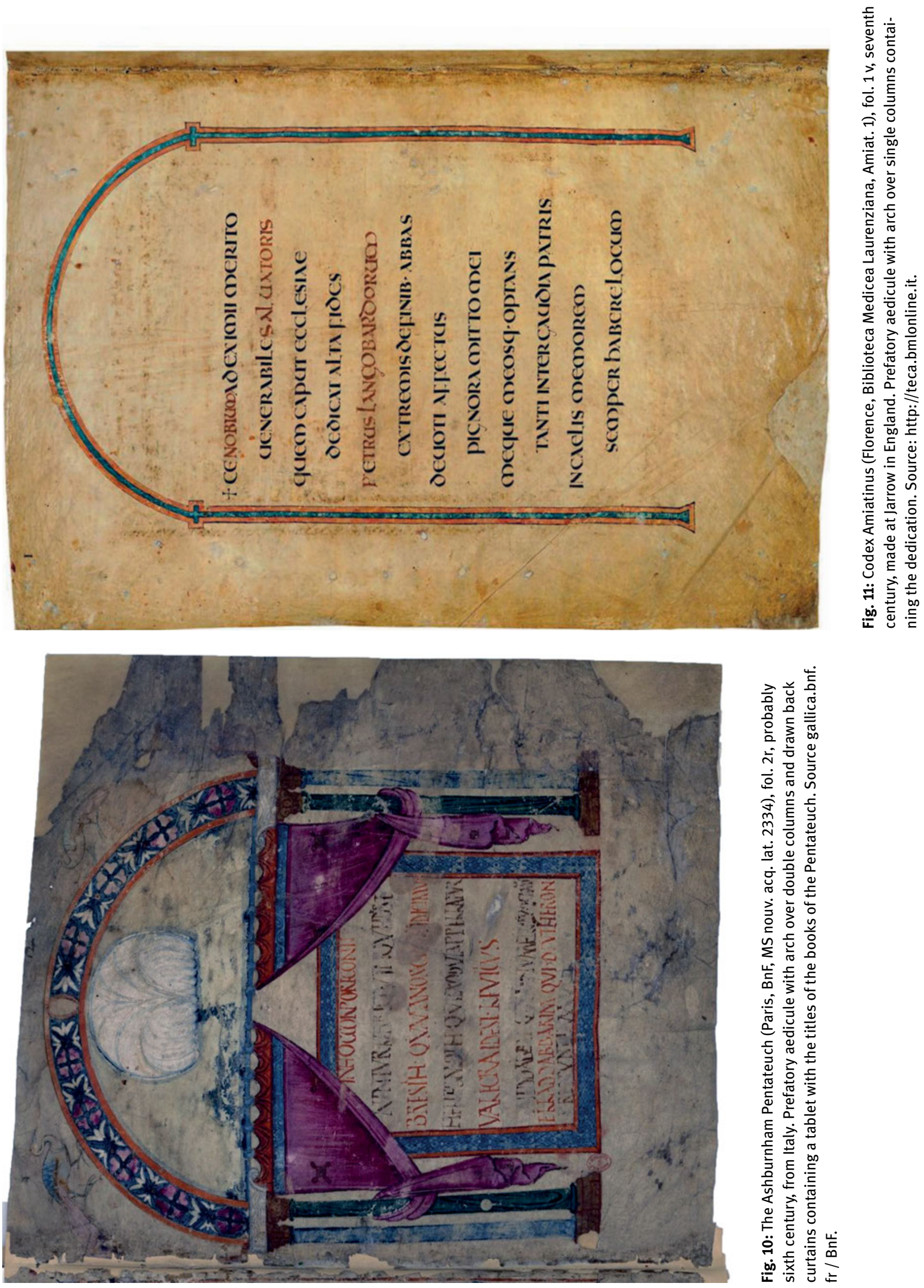

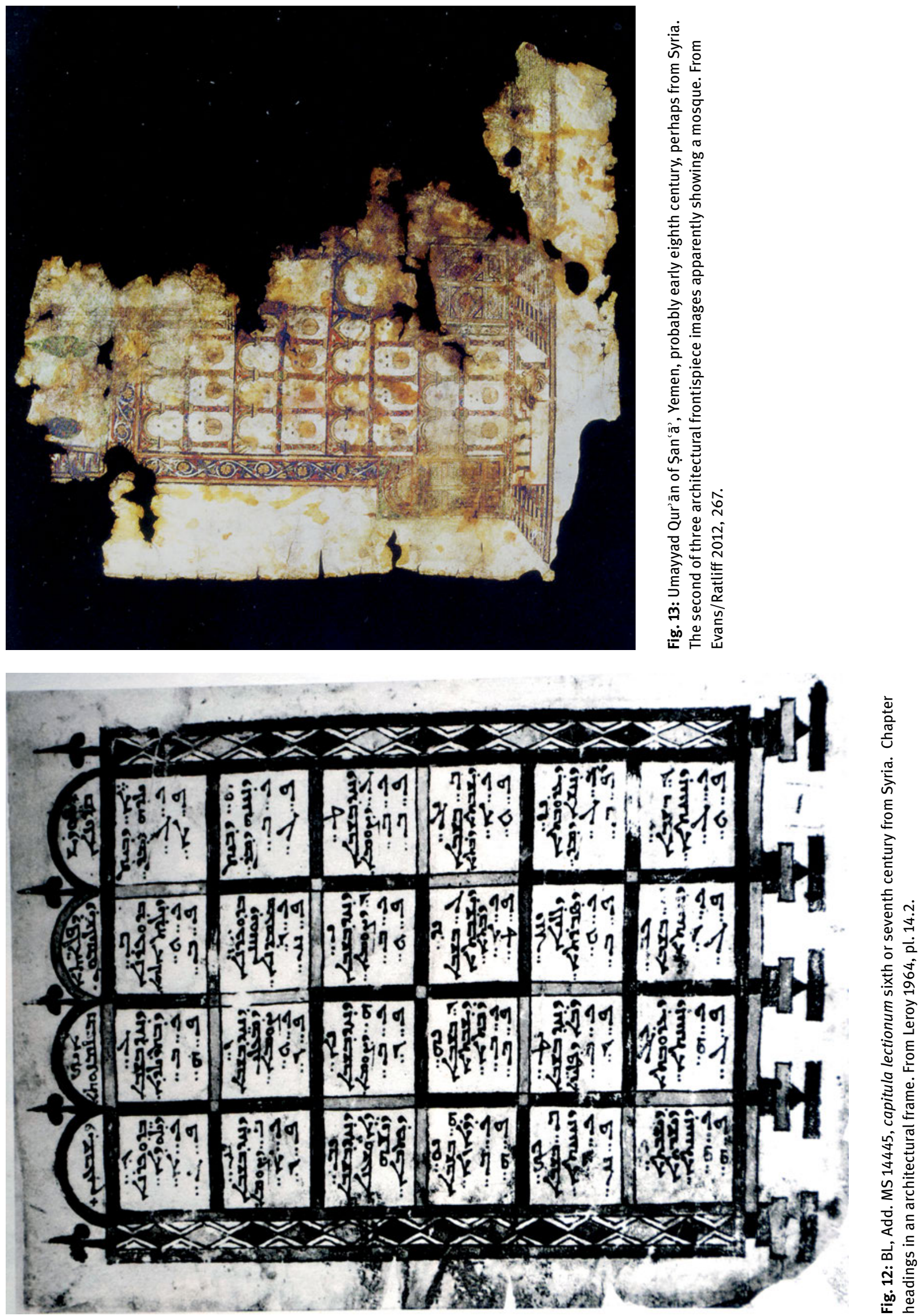

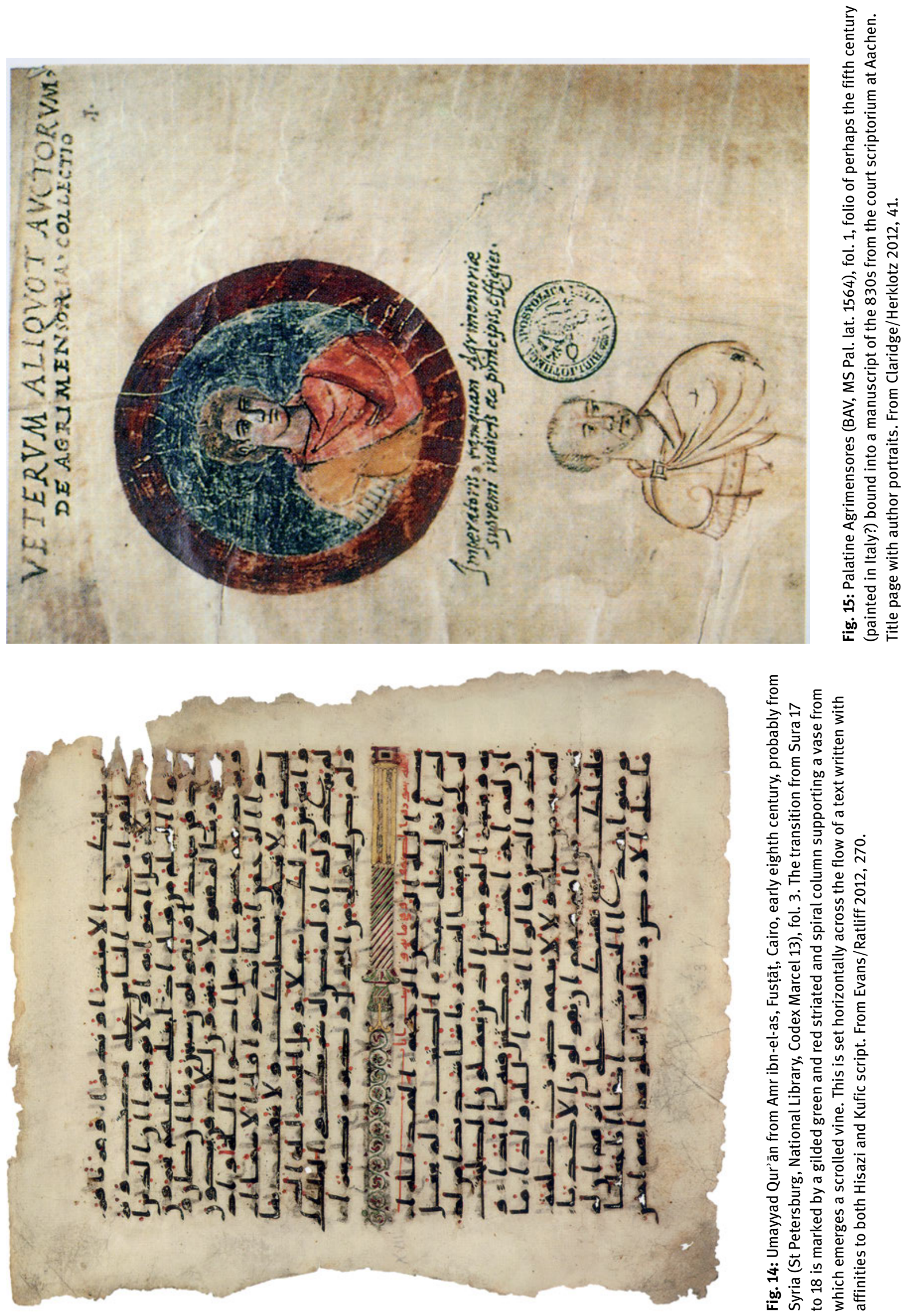


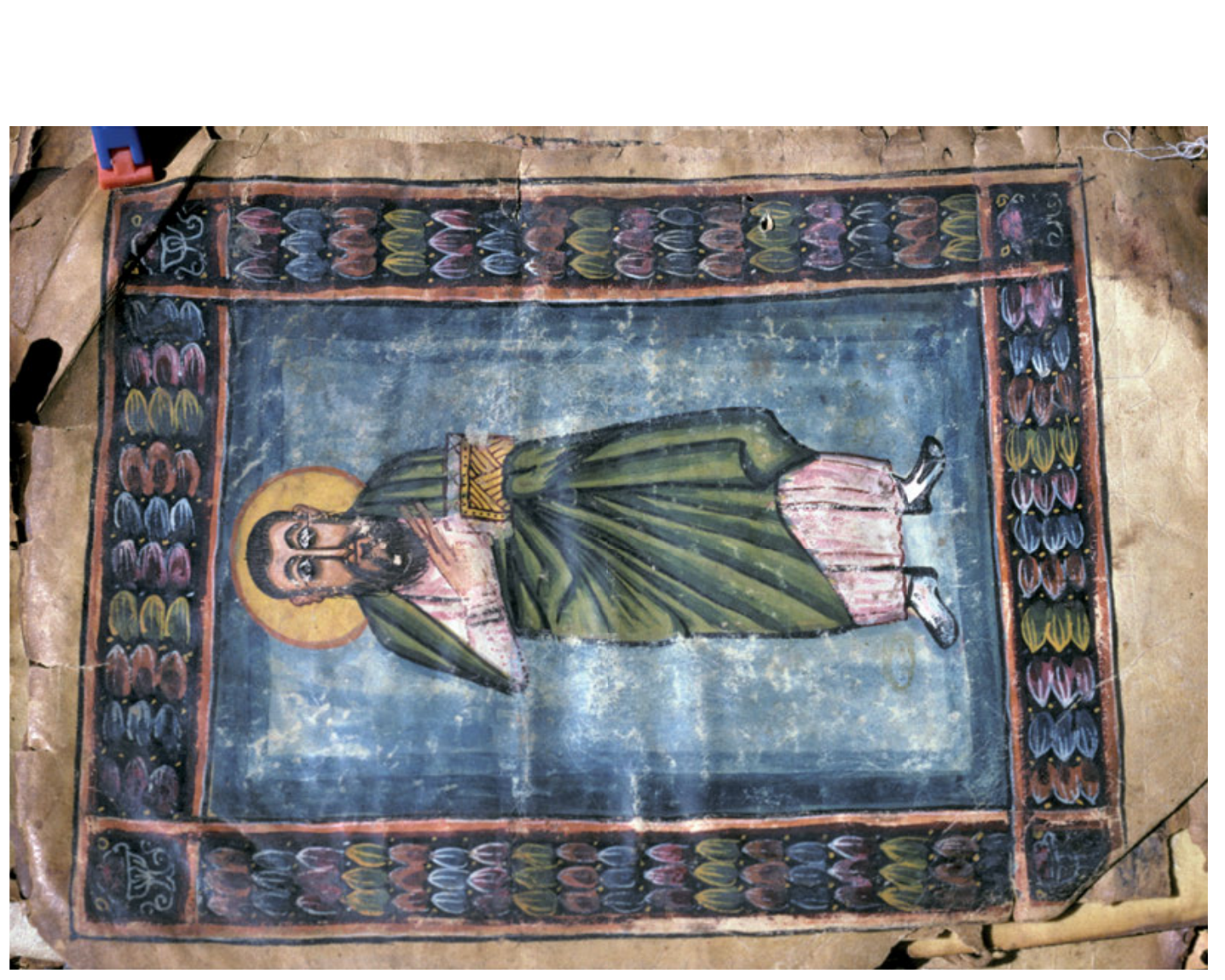

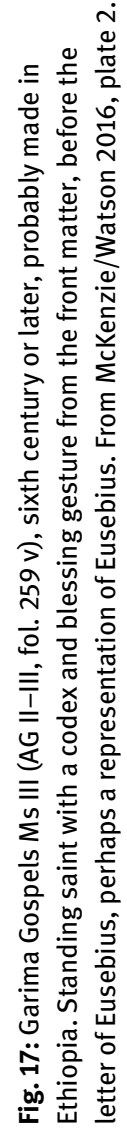
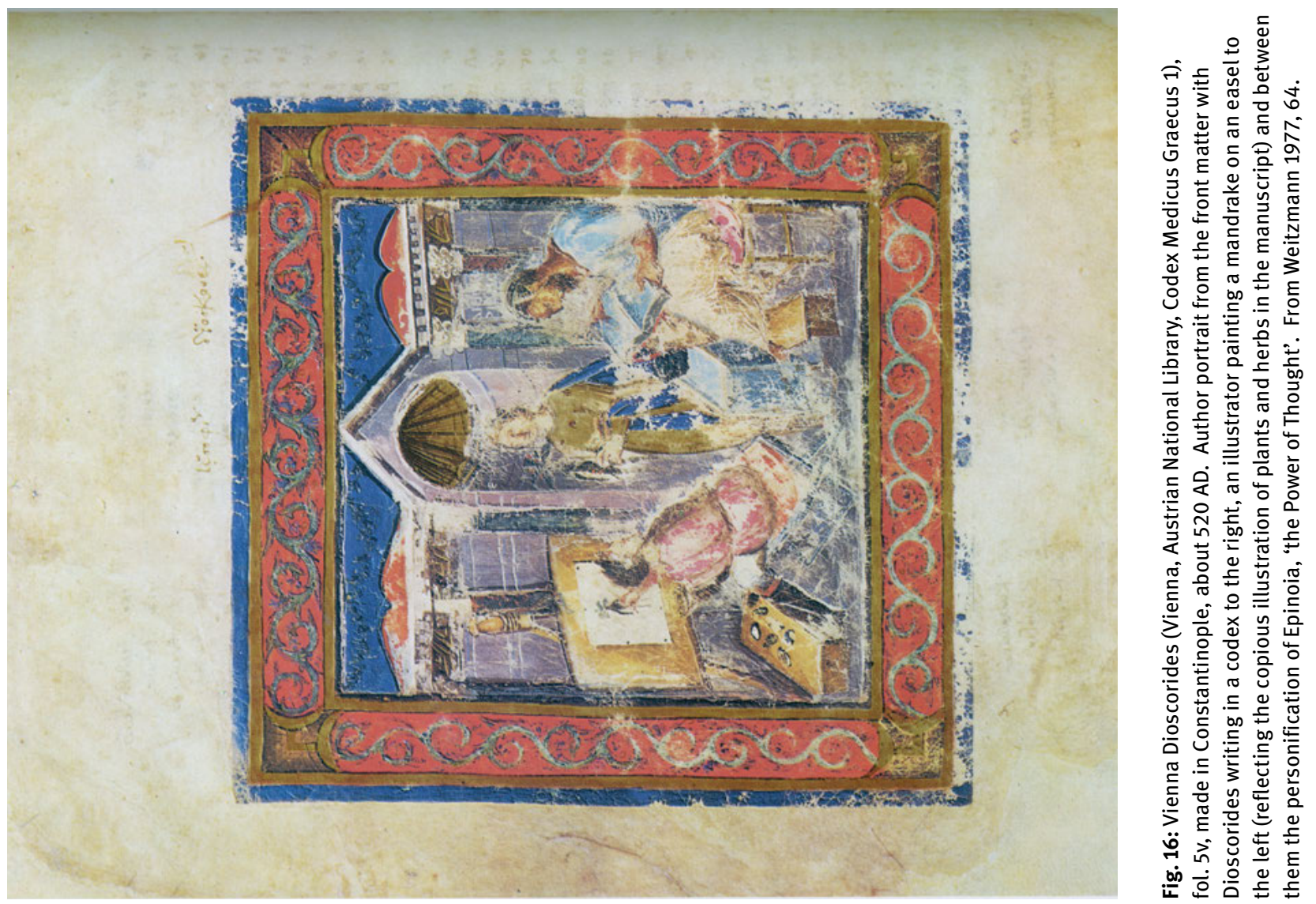

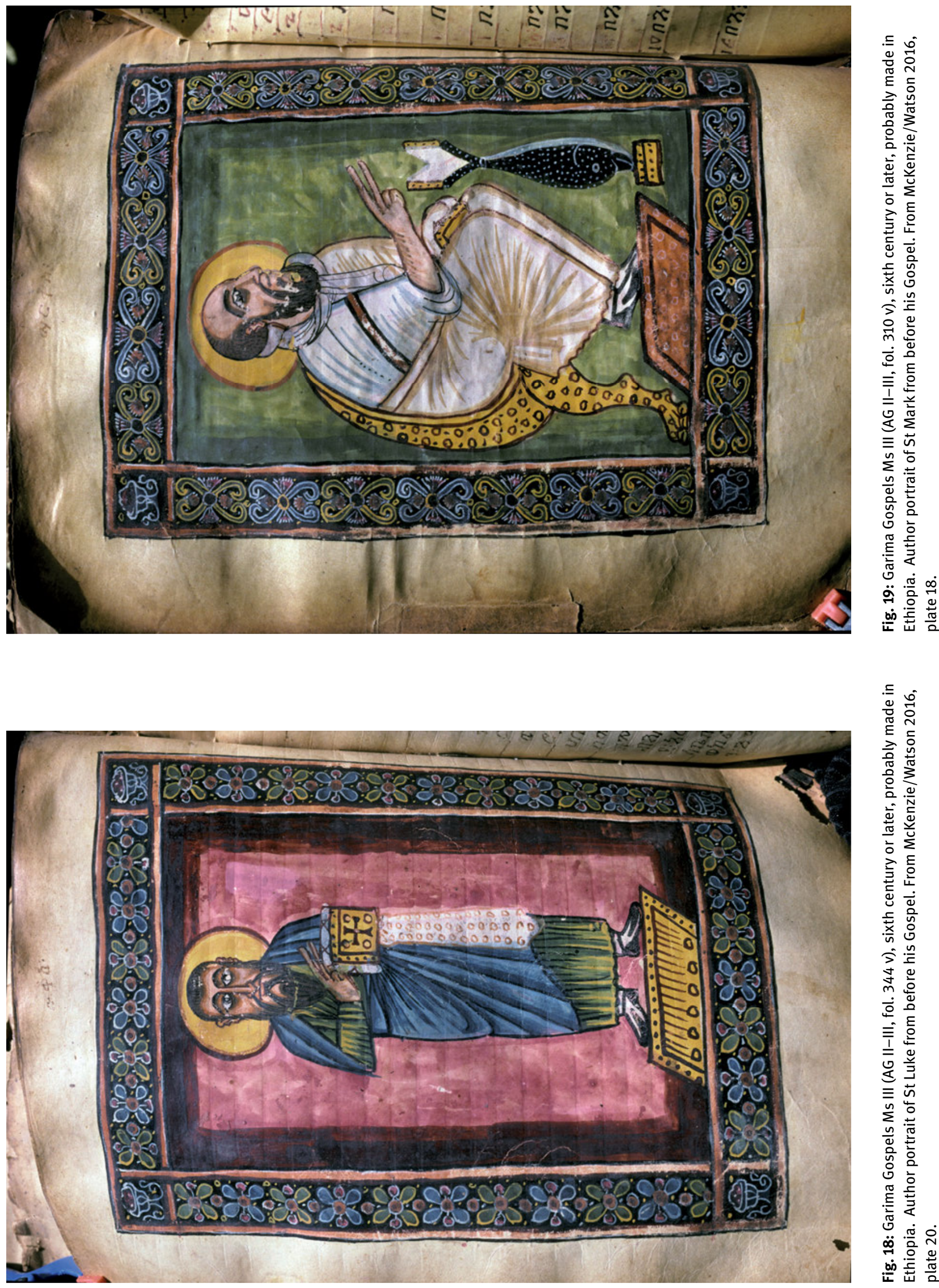


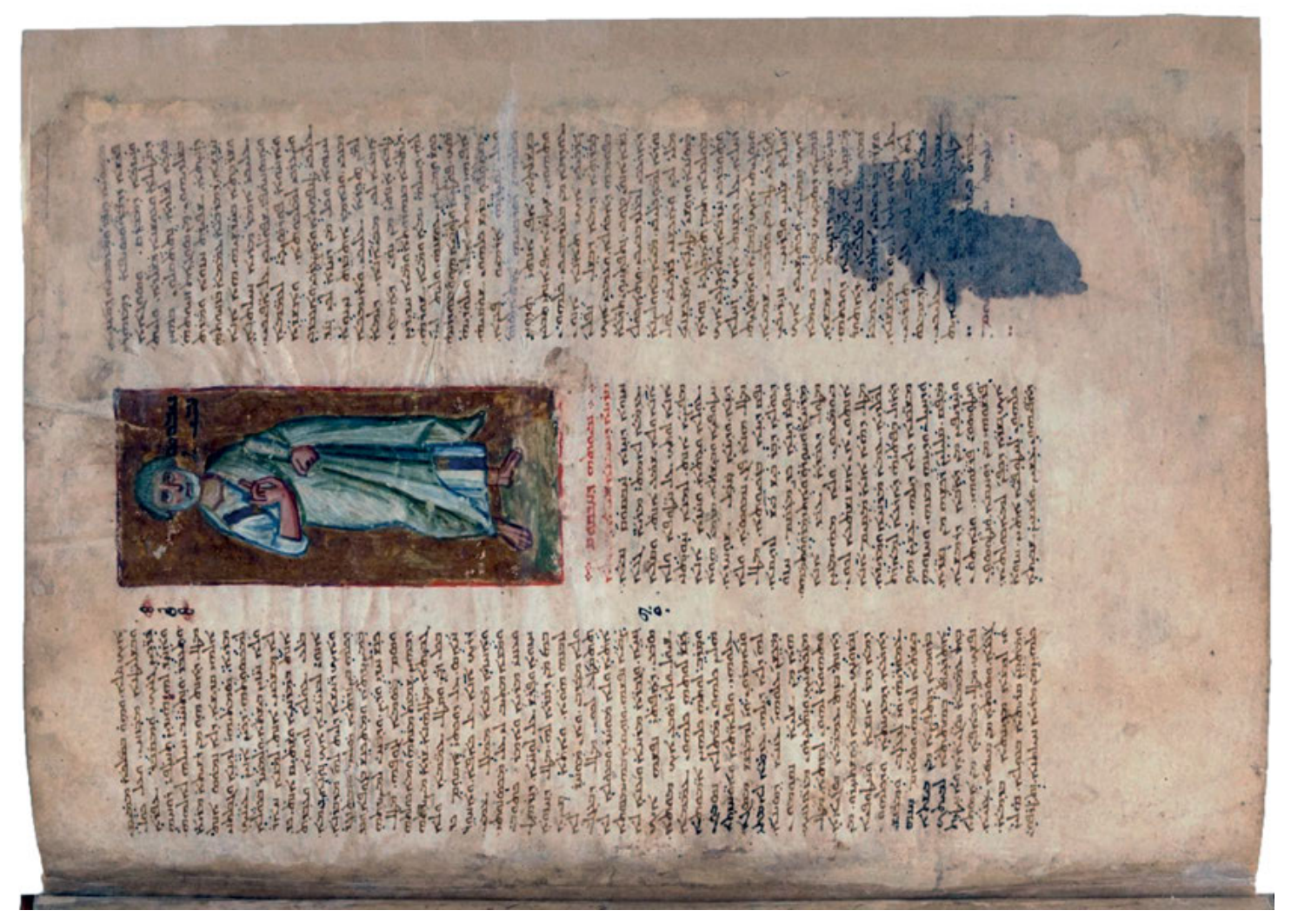

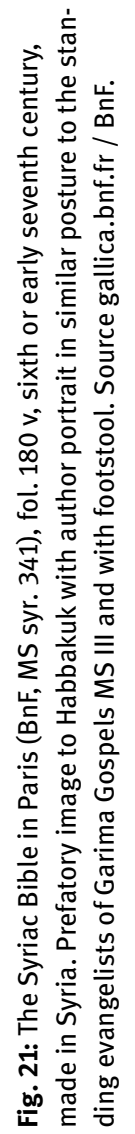
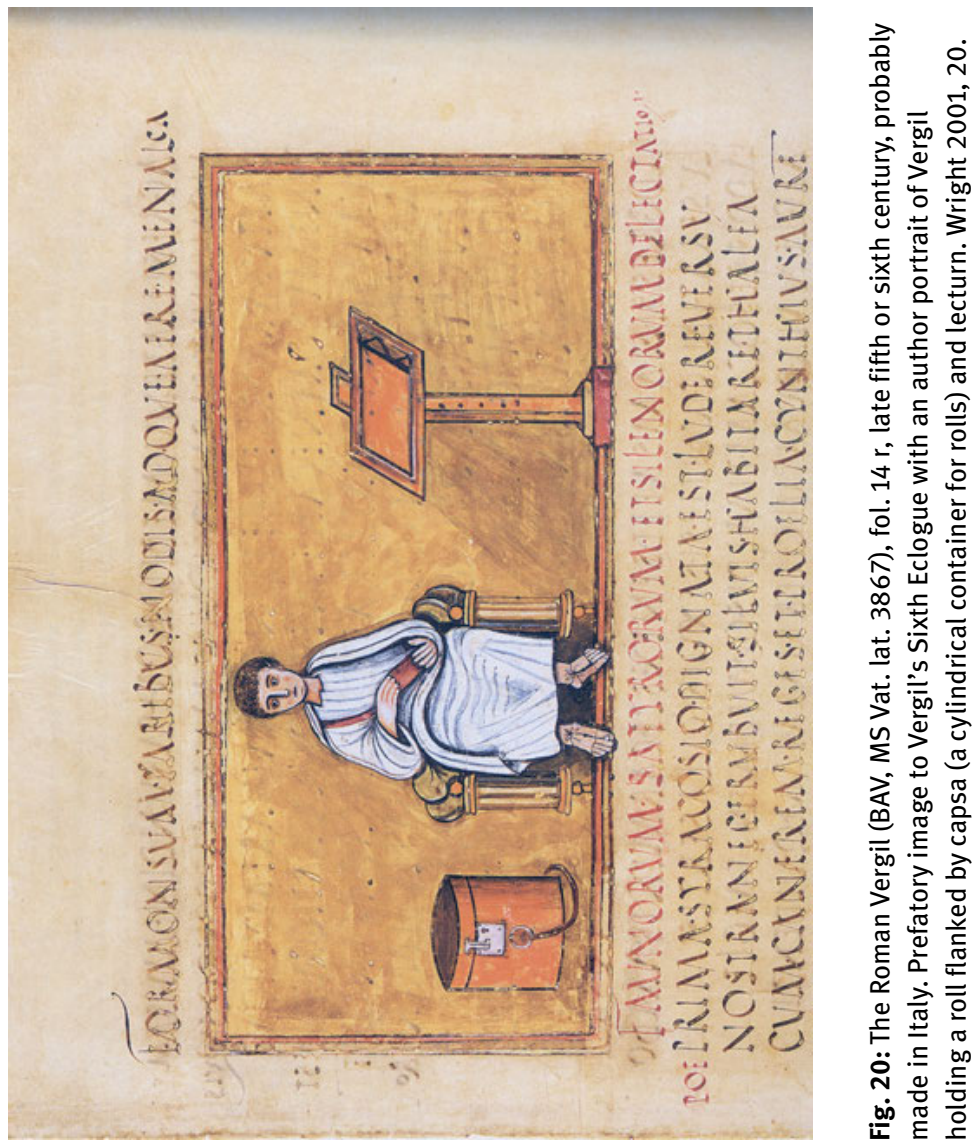

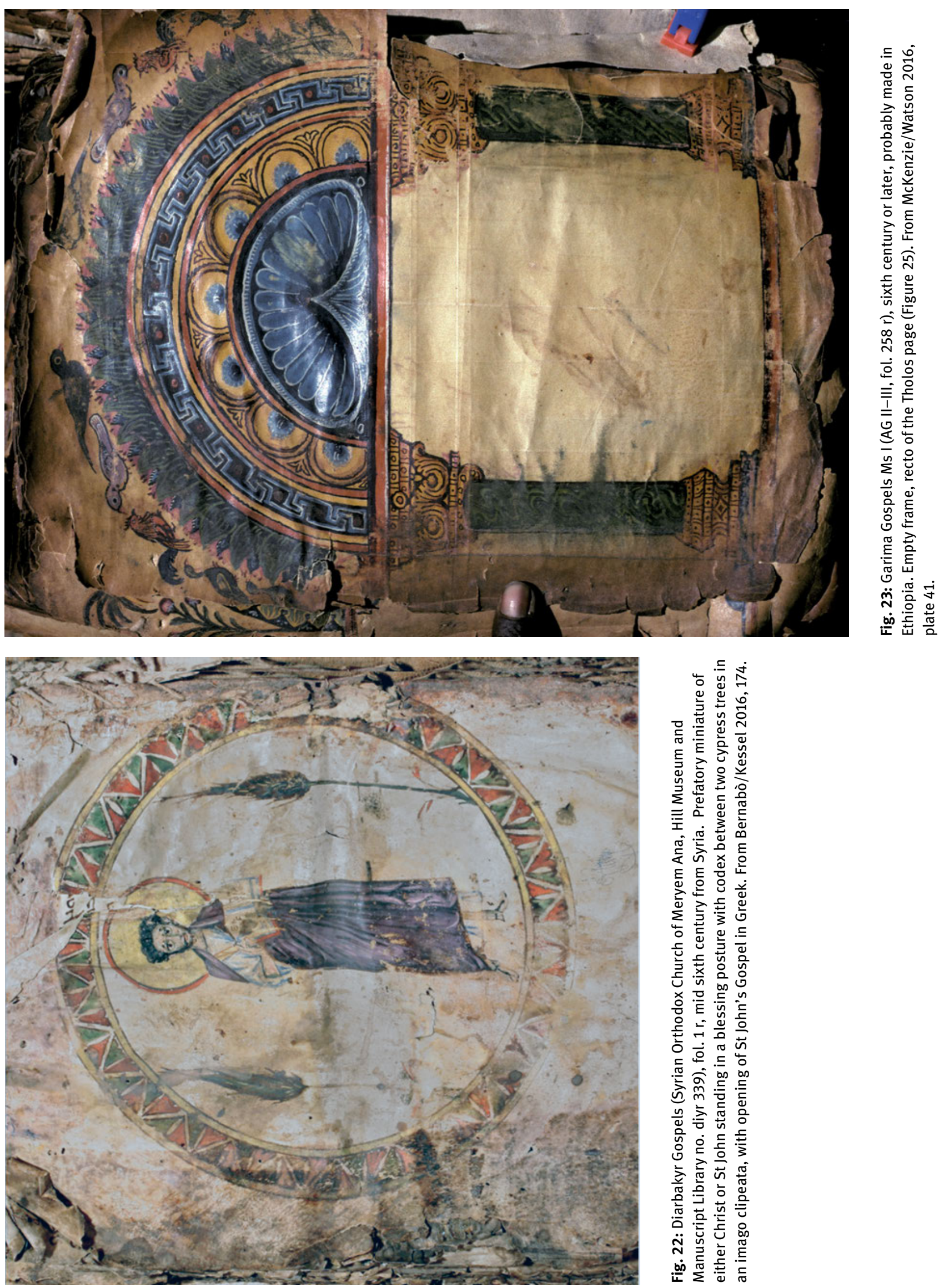

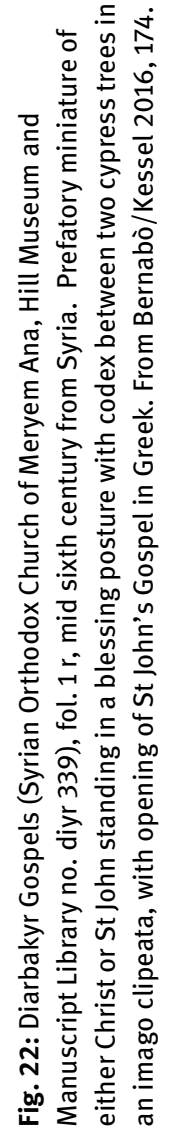



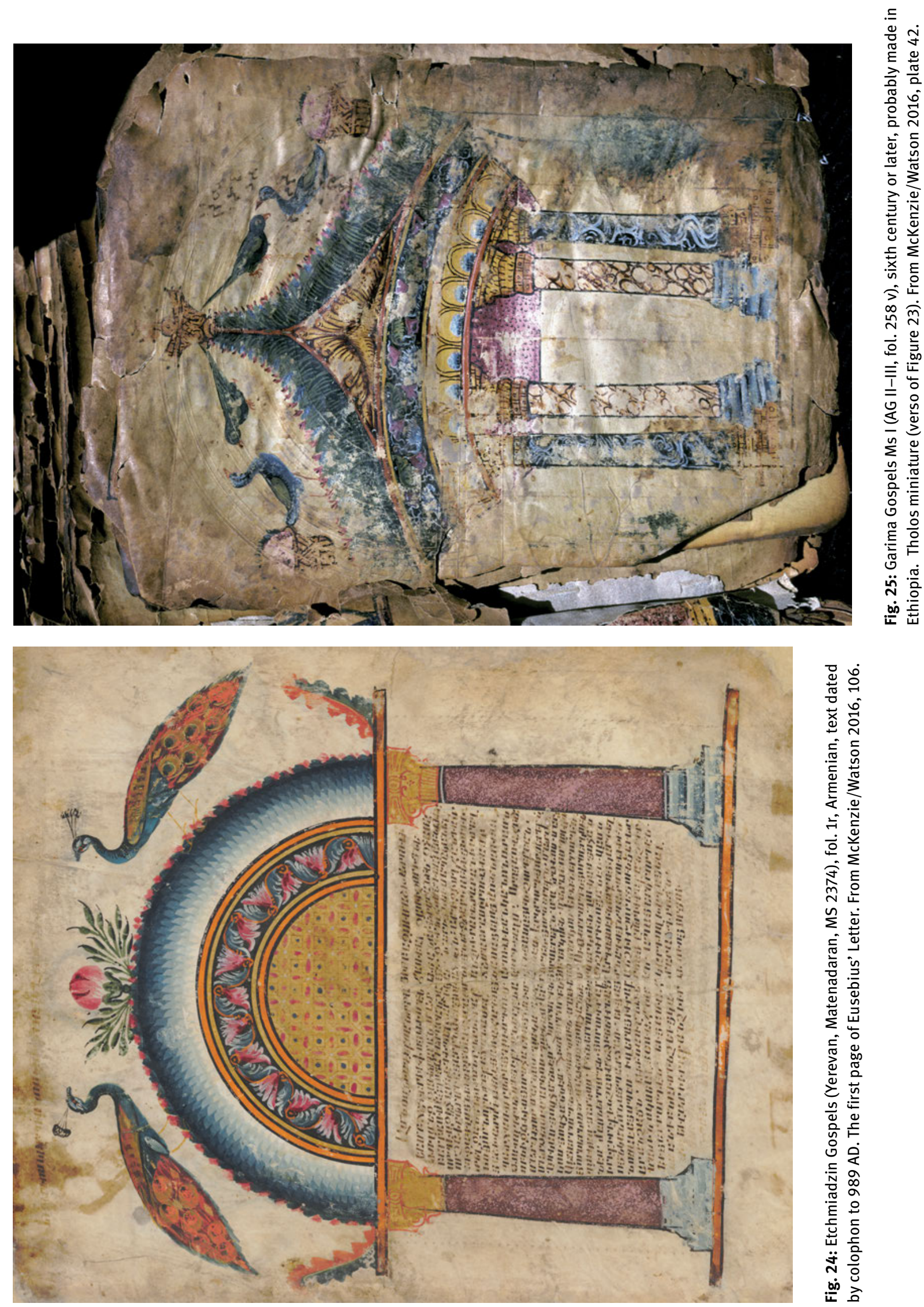

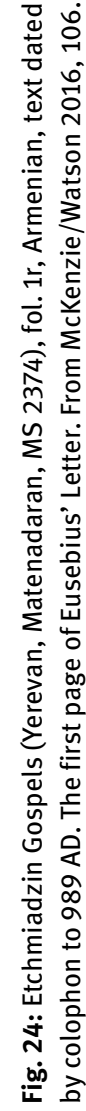




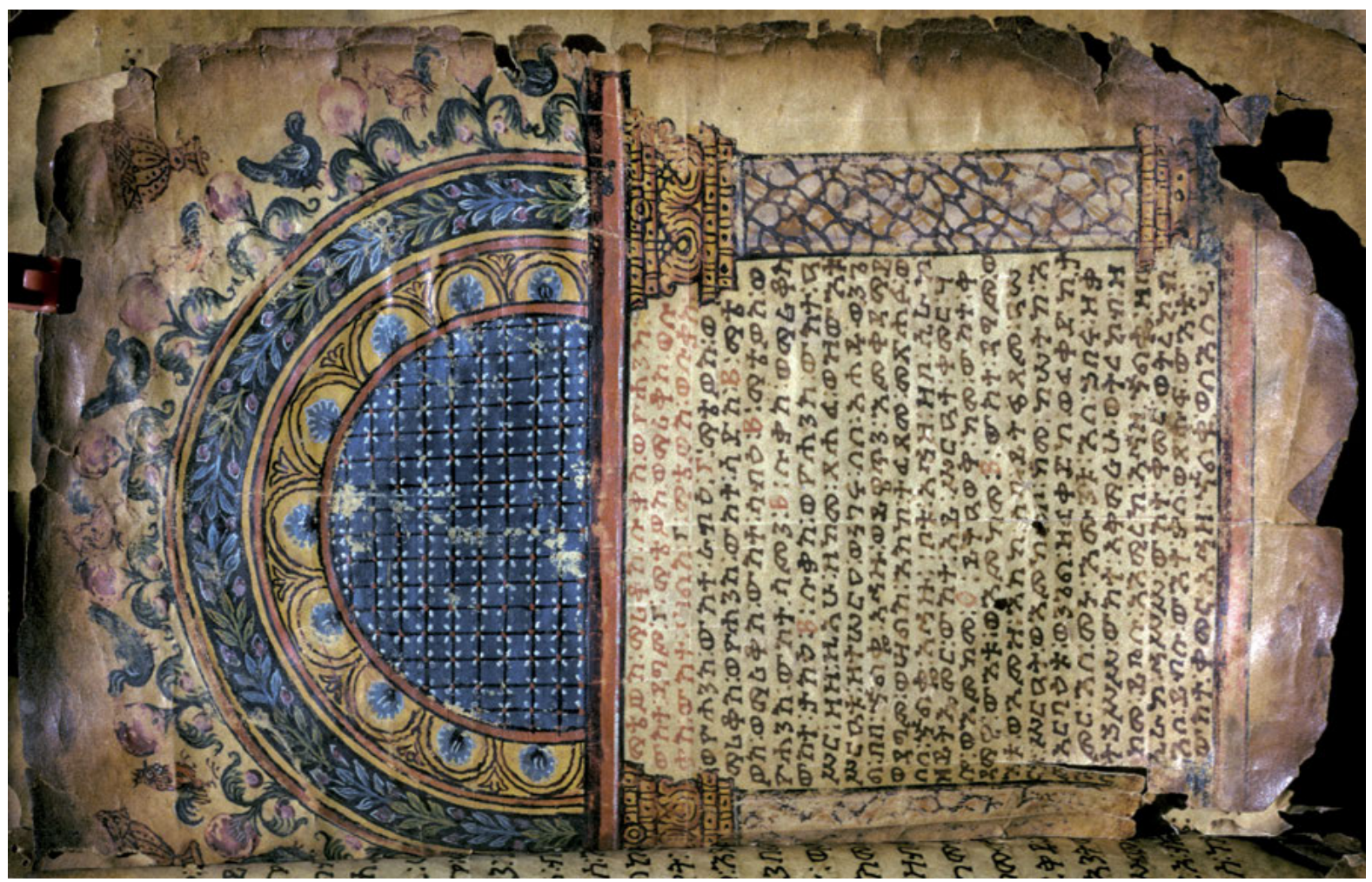

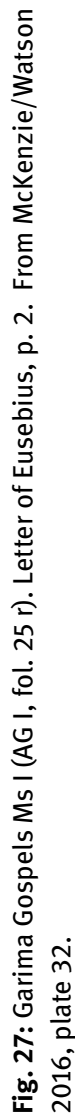

$\varangle$

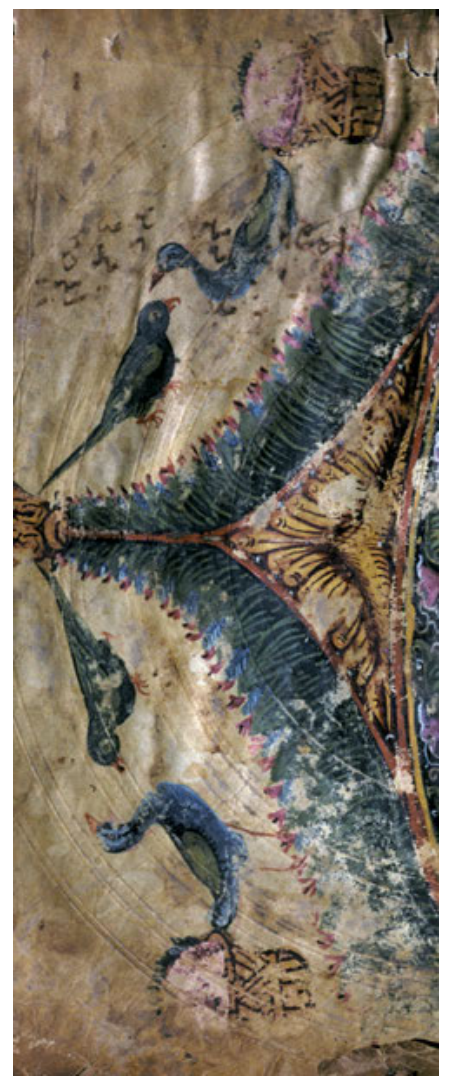

$\checkmark$

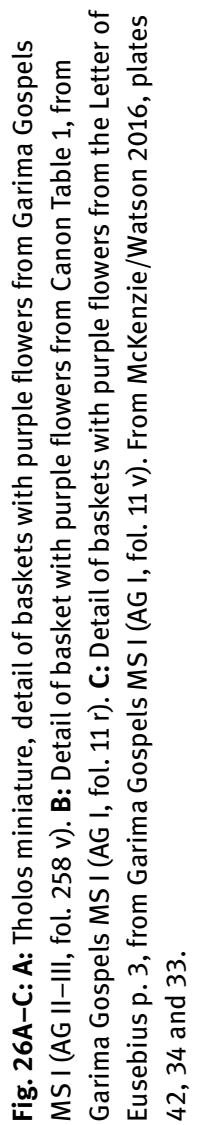

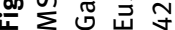

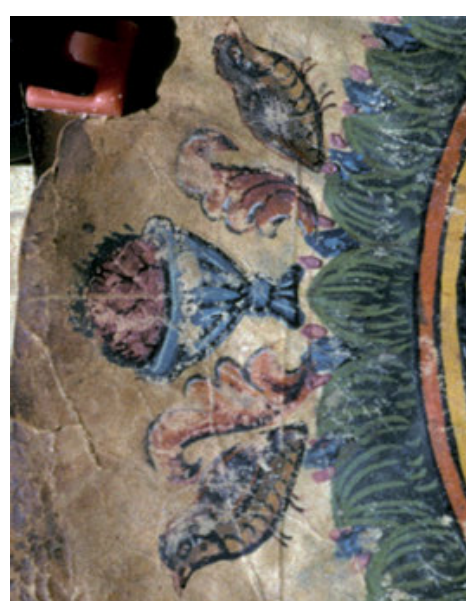

$\infty$

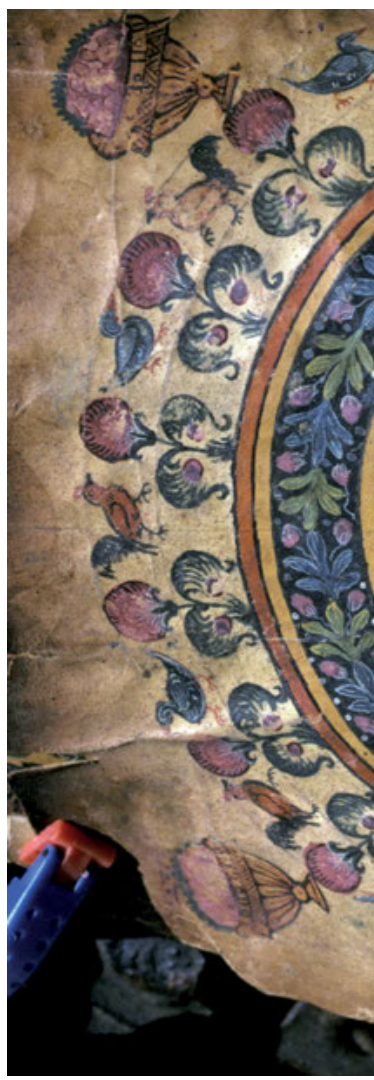



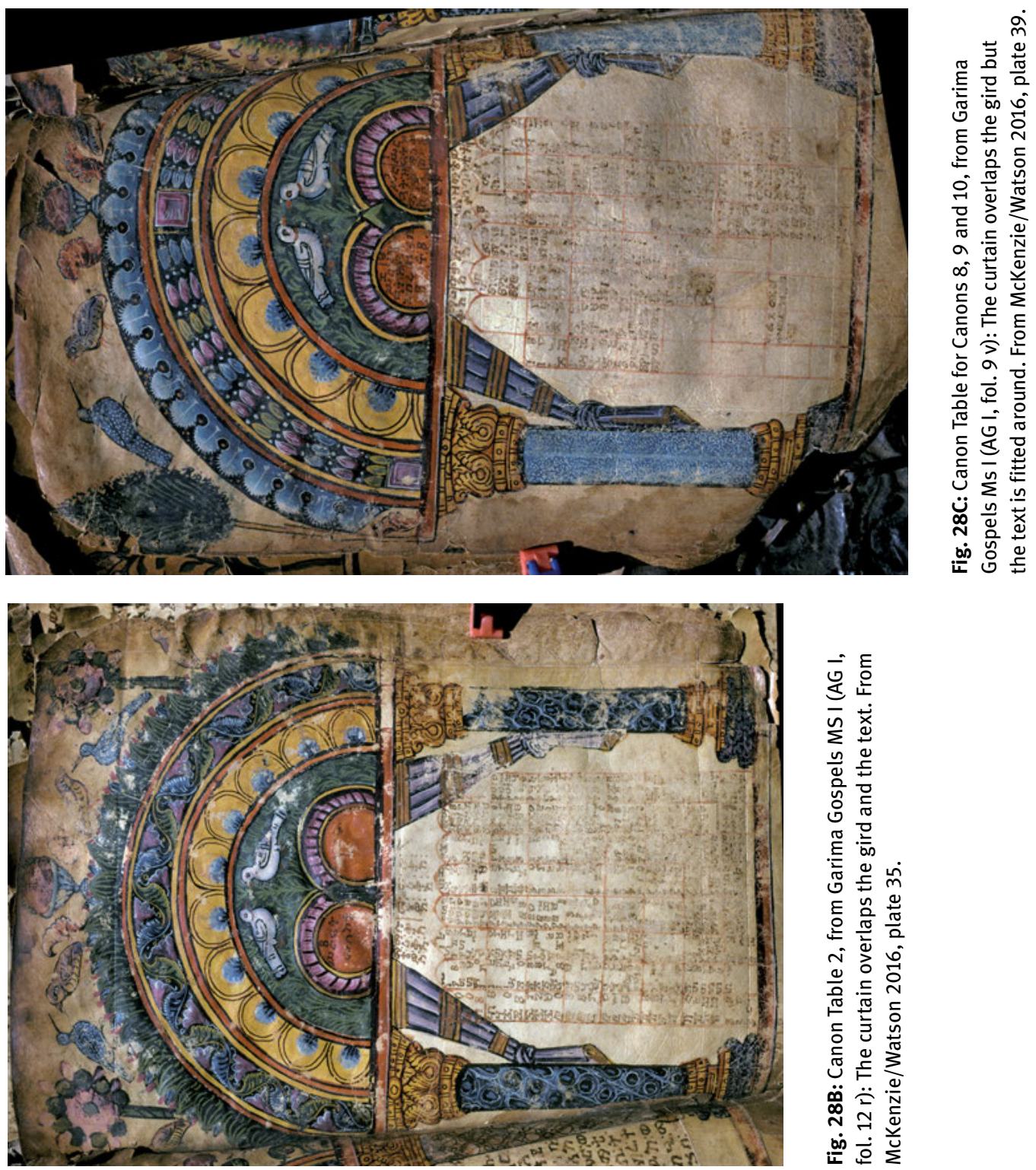

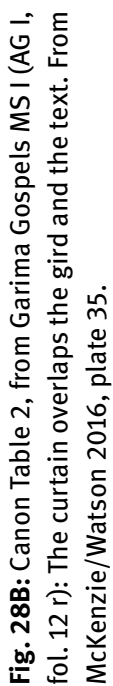

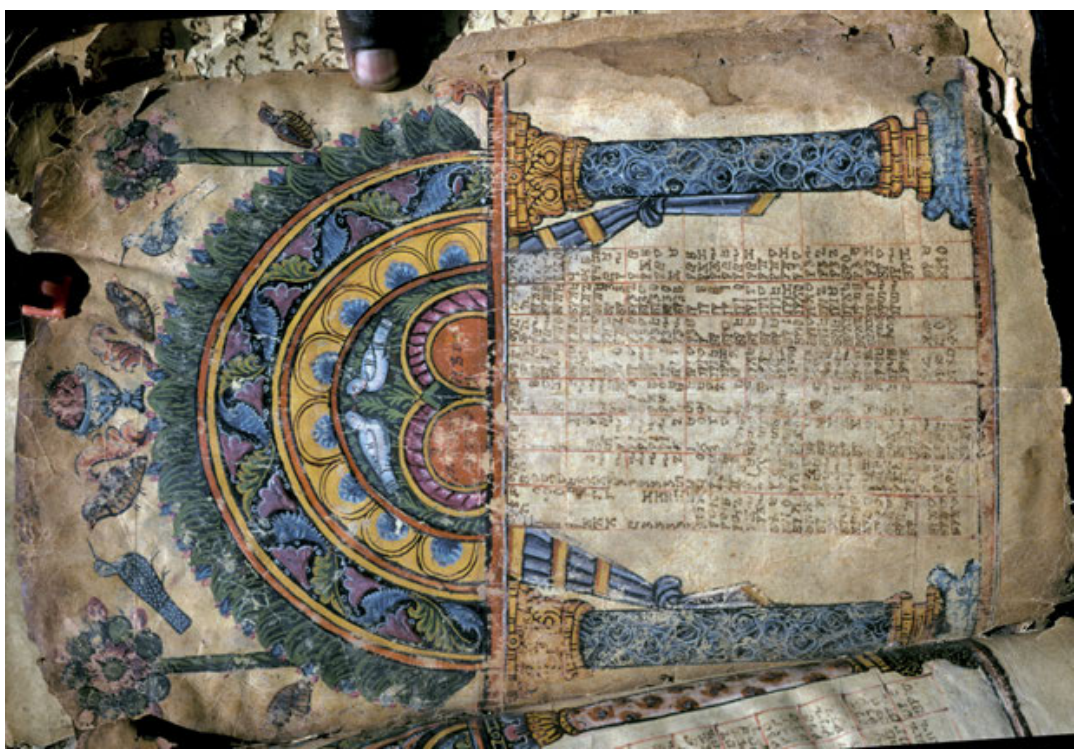

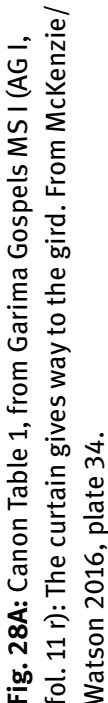




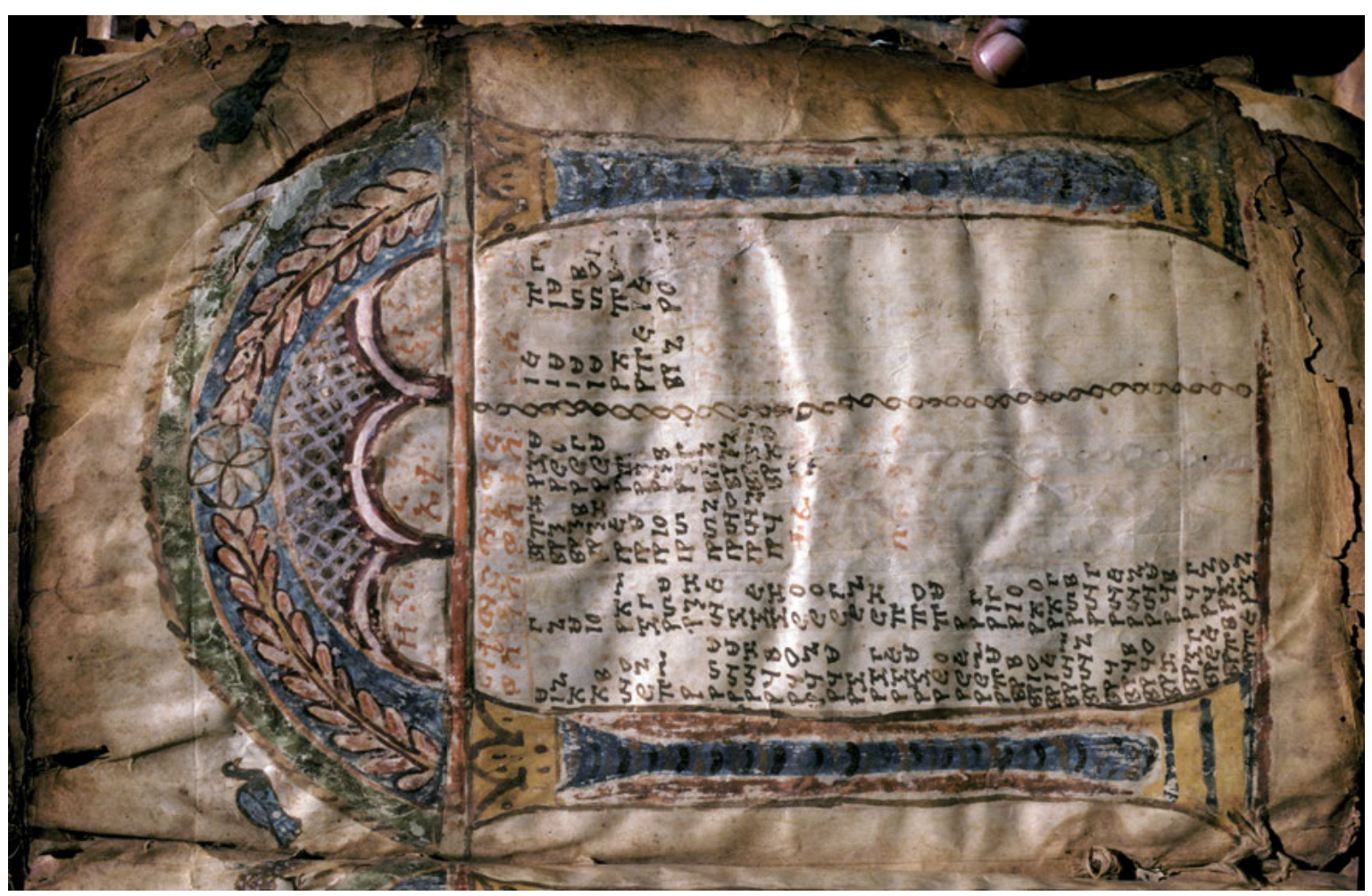

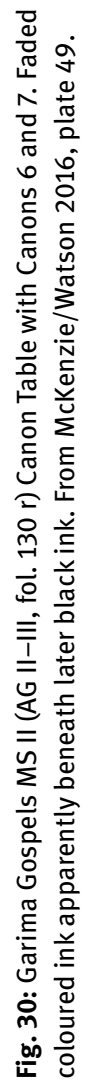

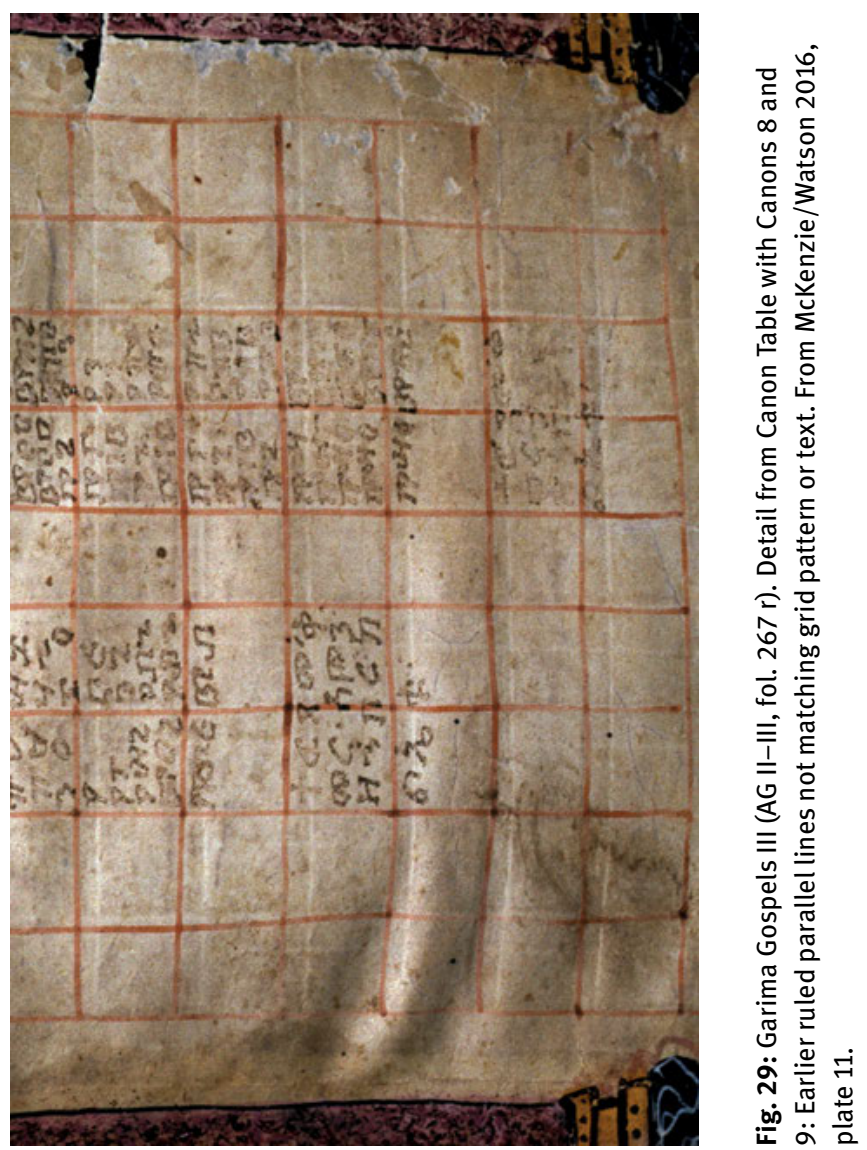




\section{References}

Alexander, Paul (1952), 'Hypatius of Ephesus: A Note on Image Worship in the Sixth Century', Harvard Theological Review, 45, 177-184.

Alexander, Paul (1955), 'An Ascetic Sect of Iconoclasts in Seventh Century Armenia', in Kurt Weitzmann (ed.), Late Classical and Medieval Studies in Honor of Albert Matthias Friend, Jr., Princeton: Princeton University Press, 151-160.

Alexopoulos, Stefanos (2015), 'When a Column Speaks: The Liturgy of the Parthenon', Dumbarton Oaks Papers, 69, 159-178.

Auzepy, Marie-Franace (2007), L'histoire des iconoclastes, Paris: Association des amis du Centre d'histoire et civilisation de Byzance.

Barasch, Moshe (1992), Icon: Studies in the History of An Idea, New York: New York University Press.

Barnard, Leslie (1973), The Graeco-Roman and Oriental Background of the Iconoclastic Controversy, Leiden: Brill.

Bartsch, Shadi (1989), Decoding the Ancient Novel: The Reader and the Role of Description in Heliodorus and Achilles Tatius, Princeton: Princeton University Press.

Bausi, Alessandro (2011), 'The "True Story” of the Abba Gärima Gospels', Comparative Oriental Manuscript Studies Newsletter, 1, 17-20.

Bausi, Alessandro (2017), 'Review of Judith McKenzie and Francis Watson, The Garima Gospels', Aethiopica, 20, 289-292.

Baynes, Norman (1960), 'Idolatry and the Early Church', Byzantine Studies and Other Essays, London: Athlone Press, 116-143.

Bernabò, Massimo (2008a), 'Fantasie novecentesche, ridipinture, fattura del codice', in Bernabò 2008c, 1-21.

Bernabò, Massimo (2008b), 'Miniature e decorazione', in Bernabò 2008c, 79-112.

Bernabò, Massimo (2014), 'The Miniatures in the Rabbula Gospels: Postscripta to a Recent Book', Dumbarton Oaks Papers, 68, 343-358.

Bernabò, Massimo (ed.) (2008c), Il Tetravangelo di Rabbula: Firenze, Biblioteca medicea laurenziana, Plut. 1.56; l'illustrazione del Nuovo Testamento nella Siria del VI secolo, Rome: Edizioni di storia e letteratura.

Bernabò, Massimo and Grigory Kessel (2016), 'A Syriac Four Gospel Book in Diyarbakır', Convivium, 3, 172-205.

Besançon, Alain (2000), The Forbidden Images: An Intellectual History of Iconoclasm, Chicago: University of Chicago Press

Blanck, Horst (1992), Das Buch in der Antike, Munich: Beck.

Borg, Barbara (2004), 'Bilder zum Hören - Bilder zum Sehen: Lukians Ekphraseis und die Rekonstruktion antiker Kunstwerke', Millennium, 1, 25-57.

von Bothmer, Hans (1986), 'Frühislamische Koran-Illuminationen: Meisterwerke aus den Handschriften der großen Moschee in Sanaa/Yemen', Kunst und Antiquitäten, 1, 22-33.

von Bothmer, Hans (1987a), 'Architekturbilder im Koran', Pantheon, 45, 4-20.

von Bothmer, Hans (1987b), 'Masterworks of Islamic Book Art', in Werner Daum (ed.), Yemen: 3000 Years of Art and Civilisation in Arabia Felix, Innsbruck: Pinguin, 178-181.

Bremmer, Jan (2008), 'Iconoclast, Iconoclastic and Iconoclasm: Notes towards a Genealogy', Church History and Religious Culture, 88, 1-17.
Brubaker, Leslie, and John Haldon (2011), Byzantium in the Iconoclast Era, c. 680-850: A History, Cambridge: Cambridge University Press.

Bruce-Mitford, Rupert (1967), The Art of the Codex Amiatinus, Oxford: Oxford University Press.

Bryer, Anthony, and Judith Herrin (eds) (1977), Iconoclasm: Papers given at the Ninth Spring Symposium of Byzantine Studies, University of Birmingham, March 1975, Birmingham: University of Birmingham.

Burgess, Richard (2012), 'The Chronograph of 354: Its Manuscripts, Contents and History', Journal of Late Antiquity, 5, 345-396.

Butzmann, Hans (1970), Corpus Agrimensorum Romanorum. Codex Arcerianus A der Herzog-August-Bibliothek zu Wolfenbüttel (Cod. Guelf. 36.23A), Leiden: Sijthoff.

Cameron, Averil (1979), 'Images of Authority: Elites and Icons in Late Sixth-Century Byzantium', Past and Present, 84, 3-35.

Campagnolo, Matteo, Paul Magdalino, Marielle Martiniani-Reber, and Andre-Louis Rey, (eds) (2015), L'aniconisme dans l'art religieux byzantin: actes du colloque de Genève (1-3 octobre 2009), Geneva: La pomme d'or.

Cannatà Fera, Maria (1998), 'Comunicazione e umorismo: L'Ippia di Luciano', in Ermanno Arslan (ed.), La 'parola' delle immagini e delle forme di scrittura. Modi e tecniche della communicazione nel mondo antico, Messina: Di.Sc.A.M: 229-242.

Carder, James (1978), Art Historical Problems of a Roman Land-Surveying Manuscript, New York: Garland.

Cavallo, Guglielmo (1997), 'Du volumen au codex: la lecture dans le monde romain', in Guglielmo Cavallo and Roger Chartier (eds), Histoire de la lecture dans le monde occidental, Paris: Seuil, 85-114.

Cavallo, Guglielmo (2010), 'Libri, lettura e biblioteche nella tarda antichità: un panorama e qualche riflessione', Antiquité Tardive, 18, 9-19.

Cavallo, Guglielmo, Jean Gribomont, and William Loerke (1987), Codex Pupureus Rossanensis, Museo dell'Arcivescovado, Rossano calabro: commentarium, Rome: Akademische Drucku. Verlagsanstalt.

Cecchelli, Carlo, Giuseppe Furlani, and Mario Salmi (1959), The Rabbula Gospels: Facsimile Edition of the Miniatures of the Syriac ms. Plut. 1, 56 in the Medicaean-Laurentian Library, Olten: Urs Graf.

Chazelle, Celia (2003), 'Ceolfrid's Gift to St Peter: The First Quire of the Codex Amiatinus and the Evidence of its Roman Destination', Early Medieval Europe, 12, 129-157.

Claridge, Amanda, and Ingo Herklotz (2012), The Paper Museum of Cassiano dal Pozzo: Classical Manuscript Illustrations, London: Harvey Miller.

Codoñer, Juan (2013), 'Melkites and Icon Worship during the Iconoclastic Period', Dumbarton Oaks Papers, 67, 135-188.

Corsano, Karen (1987), 'The First Quire of the Codex Amiatinus and the Institutiones of Cassiodorus', Scriptorium, 41, 3-34.

Crawford, Matthew (2015), “Reordering the Confusion": Tatian, the Second Sophistic and the so-called Diatessaron', Zeitschrift für Antikes Christentum, 19, 209-236.

Crawford, Matthew (2019), The Eusebian Canon Tables: Ordering Textual Knowledge in Late Antiquity, Oxford Early Christian Texts, Oxford: University Press. 
DeGregorio, Scott (2010), 'The Figure of Ezra in the Writings of Bede and the Codex Amiatinus', in Diarmuid Scully and Elizabeth Mullins (eds), Listen O Isles Unto Me: Studies in Medieval Word and Image in Honour of Jennifer O'Reilly, Cork: Cork University Press, 115-125.

Deichmann, Friedrich (1974), Ravenna: Hauptstadt des spätantiken Abendlandes, II: Kommentar, i, Stuttgart: Steiner.

Déroche, François (2004), 'Colonnes, vases et rinceaux sur quelques enluminures d'époque Omeyyade', in Comptes-rendus de séance de l'académie des inscriptions et belles-lettres, 148, 227-264.

Déroche, François (2014), Qur'ans of the Umayyads: A First Overview, Leiden: Brill.

Déroche, Vincent (1986), 'L'authenticité de l' “Apologie contre les Juifs" de Léontios de Néapolis', Bulletin de correspondance hellénique, 110, 655-669.

Déroche, Vincent (1994), 'L’Apologie contre les Juifs de Léontios de Néapolis', Travaux et memoires, 12, 45-104.

Dubel, Sandrine, and Jacques Pigeaud (2014), Lucien de Samosate: Portrait du sophiste en amateur d'art, Paris: Editions rue de l'Ulm.

Elsner, Jaś (2012), 'Iconoclasm as Discourse: From Antiquity to Byzantium', The Art Bulletin, 94, 369-395.

Elsner, Jaś, and Jésus Hernández Lobato (eds) (2017), The Poetics of Late Latin Literature, New York: Oxford University Press.

Evans, Helen, and Brandie Ratliff (eds) (2012), Byzantium and Islam: Age of Transition $7^{\text {th }}-9^{\text {th }}$ century, New Haven: Yale University Press.

Flood, Finnbar Barry (2001), The Great Mosque of Damascus: Studies on the Makings of an Umayyad Visual Culture, Leiden: Brill.

Flood, Finnbar Barry (2012), 'The Qur‘an', in Evans/Ratcliff 2012, 265-277.

Friend, Albert Matthias Jr. (1927), 'The Portraits of the Evangelists in Greek and Latin Manuscripts', Art Studies, 5, 15-47.

Friend, Albert Matthias Jr. (1929), 'The Portraits of the Evangelists in Greek and Latin Manuscripts', Art Studies, 7, 3-32.

Gallazzi, Carlo, and Salvatore Settis (eds) (2006), Le tre vite del Papiro di Artemidoro, Milan: Electa.

Gamble, Harry (2000), Books and Readers in the Early Church: A History of Early Christian Texts, New Haven: Yale University Press.

Gameson, Richard (2018), 'Codex Amiatinus: Making and Meaning', in Jarrow Lecture 2017, Jarrow: The Parish Church Council of St. Paul's Church.

von Gebhardt, Oscar (1883), The Miniatures of the Ashburnham Pentateuch, London: Asher.

Genette, Gérard (1997), Paratexts: Thresholds of Interpretation, Cambridge: Cambridge University Press.

George, Alain (2010), The Rise of Islamic Calligraphy, London: Saqi. Gero, Stephen (1975), 'Hypatius of Ephesus on the Cult of Images', in Jacob Neusner (ed.), Christianity, Judaism and Other Greco-Roman Cults: Studies for Morton Smith at Sixty, Leiden: Brill, II, 208-216.

Goeken, Johann (2009), ‘Éloge et description: l'esprit du banquet dans La Salle (Peri tou oikou) de Lucien', in Giancarlo Abbamonte, Lorenzo Miletti and Luigi Spina (eds), Discorsi alla prova, Naples: Arnaldi, 189-223.
Goldhill, Simon (2001), 'The Erotic Eye: Visual Stimulation and Cultural Conflict', in Simon Goldhill (ed.), Being Greek Under Rome, Cambridge: Cambridge University Press, 154-194.

Gorak, Jan (2013), The Making of the Modern Canon, London: Bloomsbury.

Grabar André (1957), L'iconoclasme byzantine: le dossier archéologique, Paris: Flammarion.

Grabar, André (1968), Christian Iconography: A Study of Its Origins, Princeton: Princeton University Press.

Grabar, Oleg (1992), The Mediation of Ornament, Princeton: Princeton University Press.

Grafton, Anthony, and Megan Willams (2006), Christianity and the Transformation of the Book: Origen, Eusebius, and the Library of Caesarea, Cambridge, Mass.: Harvard University Press.

Green, Roger (1991), The Works of Ausonius, Oxford: Oxford University Press.

Griffith, Sidney (1997), A Treatise on the Veneration of the Holy Icons Written in Arabic by Theodore Abū Qurrah, Bishop of Harrān (c. 755-830 AD), Louvain: Peeters.

Griffith, Sidney (2008), 'John of Damascus and the Church of Syria in the Ummayad Era: The Intellectual and Cultural Milieu of Orthodox Christians in the World of Islam', Hugoye: Journal of Syriac Studies, 11, 1-32.

Grouillard, Jean (1961), 'Hypatios d’Ephèse ou du Pseudo-Denys à Théodore Studite', Revue des études byzantines, 19, 63-75.

Haffner, Mechthild (1991), 'Die spätantiken Vorlagen und ein wiederverwendetes spätantikes Frontispiz in der Bildereinleitung eines karolingischen Agrimensorencodex', Jahrbuch für Antike und Christentum, 34, 129-138.

Halbertal, Moshe (1997), People of the Book: Canon, Meaning, and Authority, Cambridge, Mass: Harvard University Press.

Harrison, Carol, Caroline Humfress, and Isabella Sandwell (eds) (2014), Being Christian in Late Antiquity, Oxford: Oxford University Press.

Harrison, Stephen (2017), 'Metapoetics in the Prefaces of Claudian's de raptu Proserpinae', in Elsner/Hernández Lobato 2017, 236-251.

Heldman, Marilyn (1993), 'The Heritage of Late Antiquity', in Marilyn Heldman et al., African Zion: The Sacred Art of Ethiopia, New Haven: Yale University Press, 117-132.

Hinds, Stephen (2014), 'The Self-Conscious Cento', in Marco Formisano and Therese Fuhrer (eds), Décadence: 'Decline and Fall' or 'Other Antiquity', Heidelberg: Winter, 171-198.

Jansen, Laura (ed.) (2014), The Roman Paratext: Frame, Text, Readers, Cambridge: Cambridge University Press.

Jones, Alexander (1999a), Astronomical Papyri from Oxyrhynchus, Philadelphia: American Philosophical Society.

Jones, Alexander (1999b), 'A Classification of Astronomical Tables on Papyrus', in Noel Swerdlow (ed.), Ancient Astronomy and Celestial Divination, Cambridge, Mass.: MIT Press, 299-340.

Jones, Leslie Webber, and Charles Rufus Morey (1931), The Miniatures of the Manuscripts of Terence, Princeton: Princeton University Press.

Keefe, Beatrice (2015), 'Illustrating the Manuscripts of Terence' in Andrew Turner and Giulia Torello-Hill (eds), Terence Between Late Antiquity and the Age of Printing, Leiden: Brill, 36-66.

Kessler, Herbert (2008), 'The Word Made Flesh in Early Decorated Bibles', in Jeffrey Spier (ed.), Picturing the Bible: The Earliest Christian Art, New Haven: Yale University Press, 141-168. 
Kessler, Herbert, and Kurt Weitzmann (1990), The Frescoes of the Dura Synagogue and Christian Art, Washington DC: Dumbarton Oaks.

Kestner, Joseph (1973-1974), 'Ekphrasis as Frame in Longus' Daphnis and Chloe', Classical World, 67/3, 166-171.

Kitzinger, Ernst (1954), 'The Cult of Images in the Age before Iconoclasm', Dumbarton Oaks Papers, 8, 84-150.

Klingshirn, William, and Linda Safran (eds) (2007), The Early Christian Book, Washington, DC: Catholic University of America Press.

Koehler, Wilhelm, and Florentine Mütherich (1971), Die karolingischen Miniaturen, IV: Die Hofschule Kaiser Lothars: Einzelhandschriften aus Lotharingen, Berlin: Deutsche Verlag für Kunstwissenschaft.

Kozodoy, Ruth (1971), 'The Origin of Early Christian Book Illumination: The State of the Question', Gesta, 10, 33-40.

Lange, Günter (1969), Bild und Wort: die katechetische Funktion des Bildes in der griechischen Theologie des sechsten bis neunten Jahrhunderts, Würzburg: Echter.

Leroy, Jules (1957), 'Nouveau témoins des canons d'Eusèbe illustrés selon la tradition syriaque', Cahiers archéologiques, 9, 117-140.

Leroy, Jules (1960), 'L'évangéliaire éthiopien du couvent d’Abba Garima et ses attaches avec l'ancien art chrétien de Syrie', Cahiers archéologiques, 11, 131-143.

Leroy, Jules (1964), Les manuscrits syriaques à peintures conservés dans les bibliothèques d'Europe et d'Orient: contribution à l'étude de l'iconographie des Églises de langue syriaque, Paris: Geuthner.

Leroy, Jules (1968), 'Un nouvel évangéliaire éthiopien illustré du monastère d'Abba Garima', in André Grabar (ed.), Synthronon: art et archéologie de la fin de l'Antiquité et du Moyen-Âge, Paris: Klincksieck, 75-87.

Loerke, William (1961), 'The Miniatures of the Trial in the Rossano Gospels', The Art Bulletin, 43, 171-195.

Loerke, William (1995), 'Incipits and Author Portraits in Greek Gospel Books', in Christopher Moss/Katherine Keifer (eds), Byzantine East, Latin West, Princeton: Department of Art and Archaeology, Princeton University, 377-381.

Louth, Andrew (2002), St John Damascene: Tradition and Originality in Byzantine Theology, Oxford: Oxford University Press.

Lowden, John (1999), 'The Beginnings of Biblical Illustration', in Williams 1999, 9-60.

MacLean, Douglas (2003), 'Scribe as artist, not monk: the canon tables of Ailerán "the Wise” and the Book of Kells', Peritia, 17-18, 433-470.

Macler, Frédéric (1920), L'Évangile arménien: édition phototypique du manuscrit no 229 de la Bibliothèque d'Etchmiadzin, Paris: Geuthner.

Macomber, William (1979), A Catalogue of Ethiopian Manuscripts Microfilmed for the Ethiopian Manuscript Microfilm Library, Addis Ababa, and for the Monastic Microfilm Library, Collegeville, Collegeville. MN: Monastic Manuscript Microfilm Library, St. John's Abbey and University.

Maffei, Sonia (1994), Luciano di Samosata: descrizioni di opere d'arte, Turin: Einaudi.

Marsden, Richard (1996), 'Job in his Place: The Ezra Miniature in the Codex Amiatinus', Scriptorium, 49, 3-15.
Mathews, Thomas (2008/2009), 'Vrt'anēs K'ert'ot and the Early Theology of Images', Revue des études Armeniennes, 31, 101-126.

Mathews, Thomas (2016), 'The Showing of the Gospel in the Divine Liturgy', Travaux et mémoires, 20/2, Mélanges Catherine Jolivet-Lévy, Paris: Association des Amis du Centre d'Histoire et Civilisation de Byzance, 359-368.

Mathews, Thomas, and Avedis Sanjian (1991), Armenian Gospel Iconography: The Tradition of the Glajor Gospel, Washington, DC: Dumbarton Oaks.

Mazal, Otto (1999), Geschichte der Buchkultur, I: Griechischrömische Antike, Graz: Akademische Druck- $u$. Verlagsanstalt.

Mazal, Otto (ed.) (1998-1999), Der Wiener Dioskurides, 2 vols, Graz: Akad. Dr.-u.-Verl.-Anstalt.

McGill, Scott (2005), Virgil Recomposed: The Mythological and Secular Centos in Antiquity, Oxford: Oxford University Press.

McKenzie, Judith, and Francis Watson (2016), The Garima Gospels: Early Illuminated Gospel Books from Ethiopia, Manar al-Athar Monograph, 3, Oxford: Manar al-Athar.

Mercier, Jacques (2000), 'La peinture éthiopienne à l'époque Axoumite et au XVIIIe siècle', Comptes rendus des séances de l'Académie des inscriptions \& Belles-Lettres, 35-70.

Meyvaert, Paul (1996), 'Bede, Cassiodorus and the Codex Amiatinus', Speculum, 71, 827-883.

Möllendorf, Peter von (2004), 'Puzzling Beauty: zur ästhetischen Konstruktion von Paideia in Lukians “Bilder”-Dialogen', Millennium, 1, 1-24.

Morales, Helen (2004), Vision and Narrative in Achilles Tatius' 'Leucippe and Clitophon', Cambridge: Cambridge University Press

Mullins, Elizabeth (2014), 'The Eusebian Canon Tables and Hiberno-Latin Exegesis: The Case of Vienna, Österreichische Nationalbibliothek, lat. 940', Sacris Erudiri, 53, 323-344.

Muñoz, Antonio (1907), Il codice purpureo di Rossano e il frammento sinopense, Rome: Danesi.

Mütherich, Florentine (1974), 'Die karolingischen AgrimensorenCodex in Rom', Aachener Kunstblätter, 45, 59-74.

Nees, Lawrence (1999), 'Illustrated Bible from Northwest Europe', in Williams 1999, 121-177.

der Nersessian, Sirapie (1944-1945), 'Une apologie des images du septième siècle', Byzantion, 14, 58-87.

der Nersessian, Sirapie (1946), 'Image Worship in Armenia and its Opponents', Armenia Quarterly, 1, 67-81.

der Nersessian, Sirapie (1973), 'La peinture arménienne au VIle siècle et les miniatures de l'évangile d' Etchmiadzin', in Études byzantines et arméniennes/Byzantine and Armenian Studies, Louvain: Impr. Orientaliste, I, 525-532.

Netzer, Nancy (1994), Cultural Interplay in the Eighth Century: The Trier Gospels and the making of a scriptorium at Echternach, Cambridge: Cambridge University Press.

Newby, Zahra (2002), 'Testing the Boundaries of Ekphrasis: Lucian's On the Hall', Ramus, 31, 126-135.

Noble, Thomas (2009), Images, Iconoclasm and the Carolingians, Philadelphia: University of Pennsylvania Press.

Nordenfalk, Carl (1938), Die spätantiken Kanontafeln: Kunstgeschichtliche Studien über die eusebianische Evangelien-Konkordanz in den vier ersten Jahrhunderten ihrer Geschichte, I: Textband; II: Tafelband, Die Bücherornamentik der Spätantike, 1, Göteborg: Oscar Isacsons Boktryckeri A.-B. 
Nordenfalk, Carl (1982), 'Canon Tables on Papyrus', Dumbarton Oaks Papers, 36, 29-38.

Nordenfalk, Carl (1984), 'The Eusebian Canon Tables: Some Textual Problems', The Journal of Theological Studies, NS 35/1, 96-104.

Palm, Mechthild (1997), 'Zum karolingischen Agrimensoren Codex Vat. Pal. Lat. 1564', Miscellanea Bibliothecae Apostolicae Vaticanae, V, Studi e testi, 329, Vatican: Biblioteca Apostolica Vaticana, 157-173.

Pedersen, Olaf (2011), A Survey of the Almagest, London: Springer, 397-400.

Peirano, Irene (2012), The Rhetoric of the Roman Fake, Cambridge: Cambridge University Press.

Pelltari, Aaron (2014), The Space that Remains: Reading Latin Poetry in Late Antiquity, Ithaca, NY: Cornell University Press.

Platt, Verity, and Michael Squire (eds) (2017), Framing Antiquity, Cambridge: Cambridge University Press.

Polara, Giovanni (1971), Ricerche sulla tradizione manoscritta di Publilio Optaziano Porfirio, Salerno: Libreria internazionale.

Polara, Giovanni (1990), 'I centoni', in Guglielmo Cavallo, Paolo Fedeli and Andrea Giardina (eds), Lo spazio letterario di Roma antica, III: La ricezione del testo, Rome: Salerno, 245-275.

Pollmann, Karla (2004), 'Sex and Salvation in the Vergilian Cento of the Fourth Century', in Roger Rees (ed.), Romane Memento: Vergil in the Fourth Century, London: Duckworth, 79-96.

Prieto Domínguez, Oscar (2010), De alieno nostrum: El centón profano en el mundo griego, Salamanca: Ediciones Universidad de Salamanca.

Rapti, Ioanna (2015), 'Le status des images dans l'art et le culte arméniens', in Campagnolo/Magdalino/Martiniani-Reber/Rey 2015, 59-74.

Rickert, Franz (1986), Studien zur Ashburnham Pentateuch, Bonn: Rheinische Friedrich-Wilhelms-Universität Bonn.

Roberts, Colin, and Theodore Skeat (1983), The Birth of the Codex, London: British Academy.

Roby, Courtney (2017), 'Framing Technologies in Hero and Ptolemy', in Platt/Squire 2017, 514-543.

Salzman, Michelle (1990), On Roman Time: The Codex-Calendar of 354 and the Rhythms of Urban Life in Late Antiquity, Berkeley: University of California Press.

Schipke, Renate (2013), Das Buch in der Spätantike. Herstellung, Form, Ausstattung und Verbreitung in der westlichen Reichshälfte des Imperium Romanum, Wiesbaden: Reichert.

Schmid, Ulrich (2013), 'The Diatessaron of Tatian' in Bart Ehrman and Michael Holmes (eds), The Text of the New Testament in Contemporary Research: Essays on the Status Quaestionis, Leiden: Brill, 115-142.

Schwartz, Yitzchak, and Steven Fine (2012), 'llluminated Carpet Page depicting the Ark of the Covenant', in Evans/Ratliff 2012 114.

Sevrugian, Petra (2004), 'Kanontafeln', Reallexikon für Antike und Christentum, XX, Stuttgart: Hiersemann, 28-42.

Small, Jocelyn (2003), The Parallel Worlds of Classical Art and Text, Cambridge: Cambridge University Press.

Sörries, Reiner (1991), Die syrische Bibel von Paris: Paris, Bibliothèque Nationale, syr. 341; eine frühchristliche Bilderhandschrift aus dem 6. Jahrhundert, Wiesbaden: Reichert.

Sörries, Reiner (1993), Christlich-Antike Buchmalerei im Überblick, Wiesbaden: Reichert.
Squire, Michael (2009), Image and Text in Graeco-Roman Antiquity, Cambridge: Cambridge University Press.

Squire, Michael (2011), The Iliad in a Nutshell, Oxford: Oxford University Press.

Squire, Michael (2017a), 'Optatian and His Lettered Art: A Kaleidescopic Lens on Late Antiquity', in Squire/Wienand 2017, 55-120.

Squire, Michael (2017b), 'POP art: The optical poetics of Publilius Optatianus Porfyrius', in Elsner/Hernández Lobato 2017, 23-100.

Squire, Michael, and Jonas Grethlein (2014), 'Counterfeit in Character but Persuasive in Appearance: Reviewing the Ainigma of the Tabula Cebetis', Classical Philology, 109, 285-324.

Squire, Michael, and Johannes Wienand (eds) (2017), Morphogrammata / The lettered art of Optatian: figuring cultural transformations in the age of Constantine, Paderborn: Fink.

Squire, Michael, and Christopher Whitton (2017), 'Machina sacra: Optatian and the lettered art of the christogram', in Ildar Garipzanov, Catherine Goodson and Henry Maguire (eds), Graphic Signs of Identity, Faith, and Power in Late Antiquity and the Early Middle Ages, Turnhout: Brepols, 45-108.

Stanton, Graham (2004), 'The early Christian preference for the codex', in Charles Horton (ed.), The Earliest Gospels: The Origins and Transmission of the Earliest Christian Gospels. The Contribution of the Chester Beatty Gospel Codex P45, London: T. and T. Clark, 40-49.

Stroumsa, Guy (2014), 'On the Status of Books in Early Christianity', in Harrison/Humfress/Sandwell 2014, 57-72.

Thomas, Edmund (2007), Monumentality and the Roman Empire, Oxford: Oxford University Press.

Thulin, Carl (1911), Die Handschriften des Corpus Agrimensorum Romanorum, Berlin: Reimer.

Thümmel, Hans Georg (1992), Die Frühgeschichte der ostkirchlichen Bilderlehre: Texte und Untersuchungen zur Zeit vor dem Bilderstreit, Berlin: Akademie Verlag.

Torallas Tovar, Sofia, and Klaus Worp (2006), To the Origins of Greek Stenography: P. Monts. Roca I, Barcelona: Abadia de Montserrat.

van Esbroeck, Michel (2003), 'Der armenische Ikonoklasmus', Oriens Christanus, 87, 144-153.

Verkerk, Dorothy (2004), Early Medieval Bible Illumination and the Ashburnham Pentateuch, Cambridge: Cambridge University Press.

Vessey, Mark (2014), 'Fashions for Varro in Late Antiquity and Christian Ways with Books', in Harrison/Humfress/Sandwell 2014, 253-277.

Wallace-Hadrill, Andrew (2008), Rome's Cultural Revolution, Cambridge: Cambridge University Press.

Wallraff, Martin (2013a), Kodex und Kanon: Das Buch im frühen Christentum, Berlin: De Gruyter.

Wallraff, Martin (2013b), 'The Canon Tables of the Psalms: An Unknown Work of Eusebius of Caesarea', Dumbarton Oaks Papers, 67, 1-14.

Weitzmann, Kurt (1947), Illustrations in Roll and Codex: A Study of the Origin and Method of Text Illustration, Princeton: Princeton University Press.

Weitzmann, Kurt (1959), Ancient Book Illumination, Cambridge Mass: Harvard University Press. 
Weitzmann, Kurt (1977), Late Antique and Early Christian Book Illumination, London: Chatto \& Windus.

Wessel, Klaus (1968-1969), ‘Evangelisten', Reallexikon zur Byzantinischen Kunst, II, Stuttgart: Hiersemann, 452-507.

Wessel, Klaus (1976-1977), 'Kanontafeln', Reallexikon zur byzantinischen Kunst, III, Stuttgart: Hiersemann, 927-968.

Whitehouse, Helen (2016), 'Birds, Beasts and a Unicorn at Oxyrhynchus', in Gianfranco Adornato (ed.), Intorno al Papiro di Artemidoro, III: disegni, Milan: LED, 105-127.

Whitehouse, Helen (with comments by James Coulton) (2007), 'Drawing a Fine Line in Oxyrhynchus', in Alan Bowman et al., Oxyrhynchus: A City and Its Texts, London: Egypt Exploration Society, 296-306.
Williams, John (ed.) (1999), Imaging the Early Medieval Bible, University Park: Penn State Press.

Wormald, Francis (1954), The Miniatures of the Gospels of St Augustine, Cambridge: Cambridge University Press.

Wright, David (1993), The Vatican Vergil: A Masterpiece of Late Antique Art, Berkeley: University of California Press.

Wright, David (2001), The Roman Vergil and the Origins of Medieval Book Design, London: British Library.

Wright, David (2006), The Lost Late Antique Illustrated Terence, Vatican: Biblioteca Apostolica Vaticana.

Zuurmond, Rochus (2001), 'The Textual Background of the Gospel of Matthew in Ge'ez', Aethiopica, 4, 32-41. 